Prepared in cooperation with the Federal Emergency Management Agency

\title{
Assessment of the Spatial Extent and Height of Flooding in Lake Champlain During May 2011, Using Satellite Remote Sensing and Ground-Based Information
}
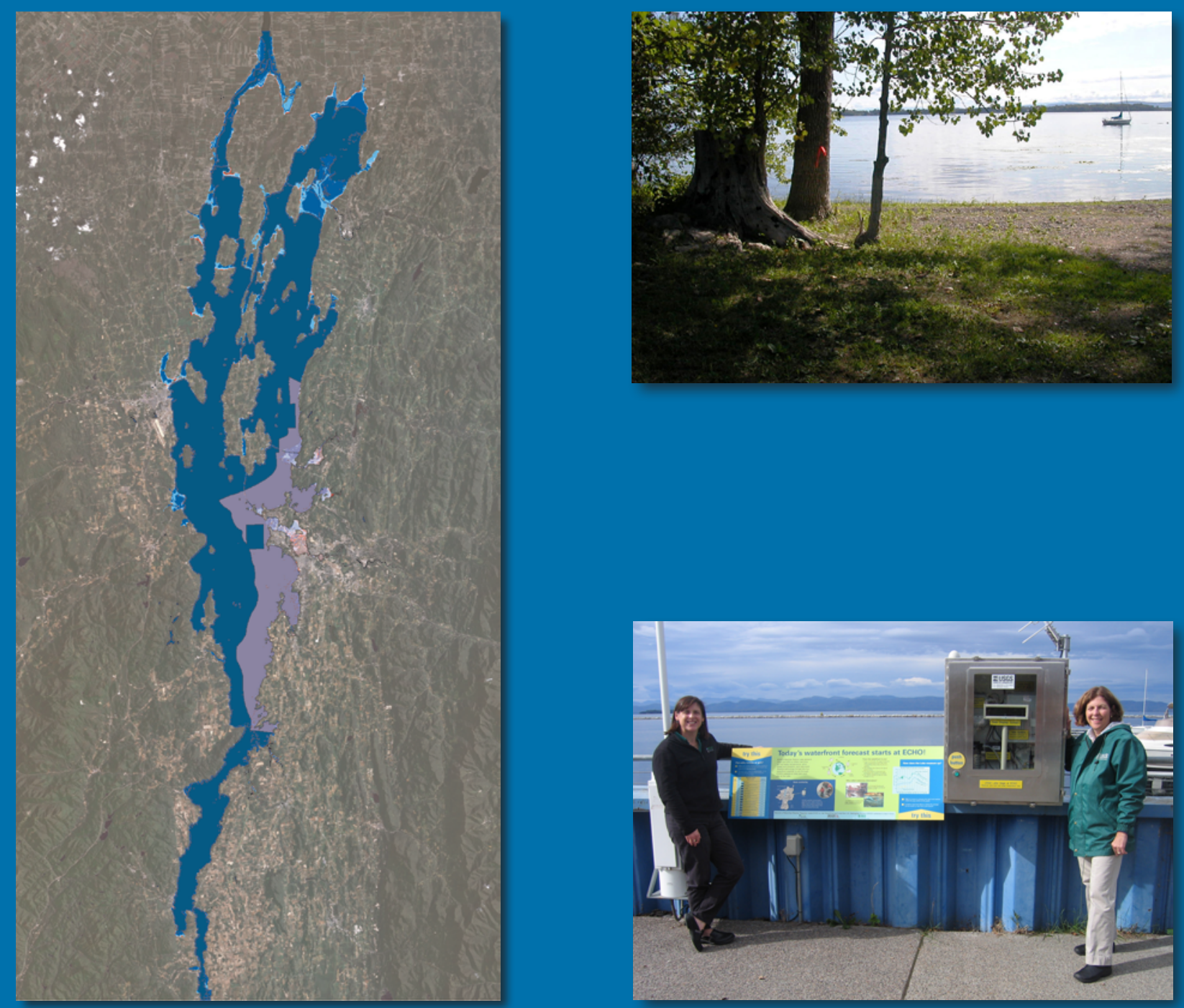

Scientific Investigations Report 2014-5163 
Cover. Map based on Landsat 5 imagery, July 2011, showing Federal Emergency Management Agency digital flood insurance rate map boundaries. Photographs: (top) high-water mark, Lake Champlain (photograph courtesy of Laura Medalie, U.S. Geological Survey); (bottom) lake gage at the ECHO Lake Aquarium and Science Center, Burlington, Vermont (photograph by Anita Cotton, U.S. Geological Survey); (back cover) sunset over Lake Champlain from Burlington, Vermont (photograph by Emily L. Morse, student, University of Connecticut). 


\section{Assessment of the Spatial Extent and Height of Flooding in Lake Champlain During May 2011, Using Satellite Remote Sensing and Ground-Based Information}

By David M. Bjerklie, Thomas J. Trombley, and Scott A. Olson

Prepared in cooperation with the Federal Emergency Management Agency

Scientific Investigations Report 2014-5163 


\title{
U.S. Department of the Interior SALLY JEWELL, Secretary
}

\section{U.S. Geological Survey Suzette M. Kimball, Acting Director}

\author{
U.S. Geological Survey, Reston, Virginia: 2014
}

For more information on the USGS - the Federal source for science about the Earth, its natural and living resources, natural hazards, and the environment, visit http://www.usgs.gov/ or call 1-888-ASK-USGS.

For an overview of USGS information products, including maps, imagery, and publications, visit http://www.usgs.gov/pubprod/

To order this and other USGS information products, visit http://store.usgs.gov/

Any use of trade, firm, or product names is for descriptive purposes only and does not imply endorsement by the U.S. Government.

Although this information product, for the most part, is in the public domain, it also may contain copyrighted materials as noted in the text. Permission to reproduce copyrighted items must be secured from the copyright owner.

Suggested citation:

Bjerklie, D.M., Trombley, T.J., and Olson, S.A., 2014, Assessment of the spatial extent and height of flooding in Lake Champlain during May 2011, using satellite remote sensing and ground-based information: U.S. Geological Survey Scientific Investigations Report 2014-5163, 18 p., http://dx.doi.org/10.3133/sir20145163.

ISSN 2328-0328 (online) 


\section{Acknowledgments}

The authors would like to thank John Mullaney, U.S. Geological Survey (USGS) New England Water Science Center, Connecticut Office, for invaluable assistance with technical and review support, and Kenneth W. Toppin, USGS New England Water Science Center, Chief, New Hampshire-Vermont Office, for invaluable review and comments. We would also like to thank Eric Howe, Technical Coordinator for the Lake Champlain Basin Program, and Greg Hanson from the National Weather Service for their insightful reviews of the report. 



\section{Contents}

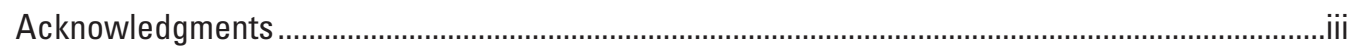

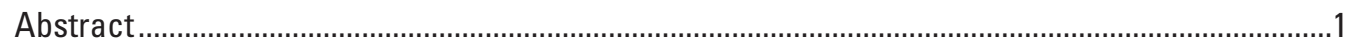

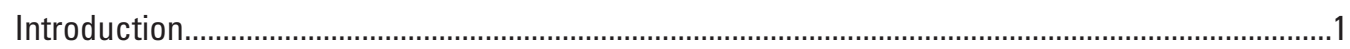

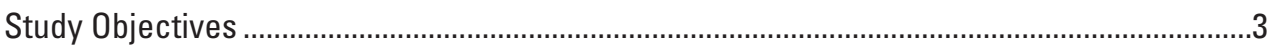

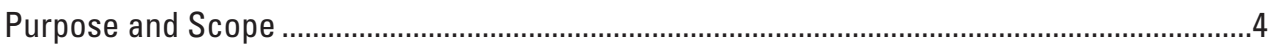

Weather and Climatic Conditions During Winter and Spring, 2010-2011......................................

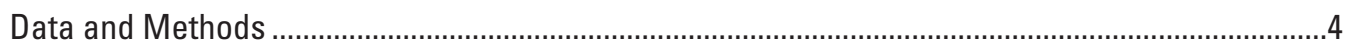

Lake Stage Records and River Inflows During Late April Through Early June 2011 .................5

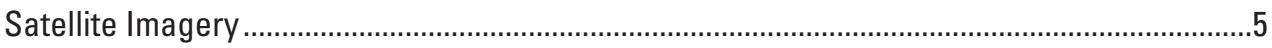

Topography and Ground Level Data—Digital Elevation Models ...............................................9

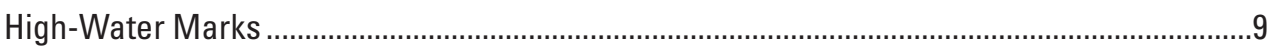

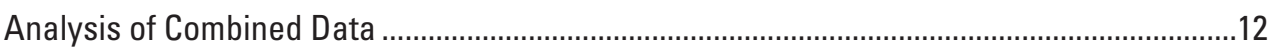

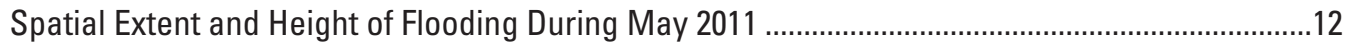

Water-Level Variations Across Lake Champlain During May 2011 .................................................12

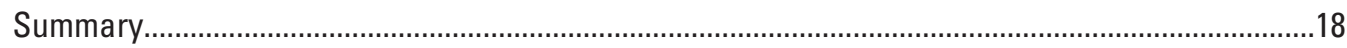

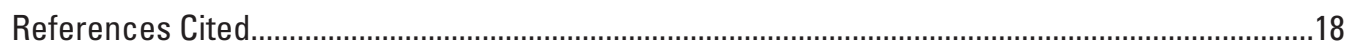

\section{Figures}

1. Map showing Lake Champlain Watershed and U.S. Geological Survey streamgages and lake/reservoir stage gages.

2. Graph showing daily mean lake level at the Burlington, Vermont, Rouses Point, and Whitehall, New York, gages from April to June 2011 .....................................................

3. Graph showing 15-minute lake level at the Rouses Point, New York, Burlington, Vermont, and Whitehall, N.Y., gages for the period from April to June 2011 ...

4. Hydrographs of daily mean river inflows to Lake Champlain measured at U.S. Geological Survey streamgages, daily mean outflow from the lake in the Richelieu River measured at Fryers Dam, and daily mean lake levels measured at Rouses Point, New York, Burlington, Vermont, and Whitehall, N.Y., between April 28 and June 15,2011 . $A$, the inflow hydrographs for rivers in Vermont and the lake levels; $B$, the inflow hydrographs for rivers in New York and the lake levels; and $C$, the outflow hydrograph for the Richelieu River and the lake levels......................................8

5. Landsat 5 image (bands 3, 4 and 5) of Lake Champlain. $A$, May 11, 2011, and $B$, July 14, 2011

6. Landsat 5 and moderate resolution imaging spectroradiometer (MODIS) images of Lake Champlain. $A$, Landsat 5, May 11, 2011, and B, AQUA MODIS, May 11, 2011 ........11

7. Graph showing relation between lake area, based on the corrected moderate resolution imaging spectroradiometer (MODIS) image and the 10-meter digital elevation model (DEM), and average lake level (stage) 
8. Map of the inundated area of Lake Champlain on May 11, 2011, from Landsat and moderate resolution imaging spectroradiometer (MODIS) imagery, showing the location and level of high-water marks around the lake, the lake level associated with graduated intervals of normal lake surface and flooded areas, and the digital flood insurance rate map boundaries for Chittenden County obtained from the Federal Emergency Management Agency (FEMA) and the Vermont Department of Environmental Conservation

9. Graph showing differences in daily mean water levels, plotted against day from April to June 2011, between the Rouses Point and Whitehall gages

\section{Tables}

1. Landsat and moderate resolution imaging spectroradiometer (MODIS) imagery available for flood period.

2. Location and level of high-water marks (HWM) identified on the Vermont side of Lake Champlain

3. Flooded area and lake stage from Landsat, moderate resolution imaging spectroradiometer (MODIS), corrected MODIS, and the 10-meter digital elevation model (DEM)

4. Stage/area rating data from imagery and from the digital elevation model (DEM) ........14

\section{Conversion Factors and Datum}

Inch/Pound to SI

\begin{tabular}{lcl}
\hline \multicolumn{1}{c}{ Multiply } & By & \multicolumn{1}{c}{ To obtain } \\
\hline foot $(\mathrm{ft})$ & Length & meter $(\mathrm{m})$ \\
mile $(\mathrm{mi})$ & 0.3048 & kilometer $(\mathrm{km})$ \\
\hline & 1.609 & \\
\hline acre & Area & square meter $\left(\mathrm{m}^{2}\right)$ \\
acre & 4,047 & hectare $($ ha) \\
acre & 0.4047 & square kilometer $\left(\mathrm{km}^{2}\right)$ \\
square foot $\left(\mathrm{ft}^{2}\right)$ & 0.004047 & square meter $\left(\mathrm{m}^{2}\right)$ \\
section $\left(640 \mathrm{acres}^{2}\right.$ or $1 \mathrm{square}$ mile $)$ & 0.09290 & square hectometer $\left(\mathrm{hm}^{2}\right)$ \\
square mile $\left(\mathrm{mi}^{2}\right)$ & 259.0 & hectare $($ ha) \\
square mile $\left(\mathrm{mi}^{2}\right)$ & 259.0 & square kilometer $\left(\mathrm{km}^{2}\right)$ \\
\hline & 2.590 & \\
\hline cubic foot $\left(\mathrm{ft}^{3}\right)$ & Volume & cubic meter $\left(\mathrm{m}^{3}\right)$ \\
acre-foot $(\mathrm{acre}-\mathrm{ft})$ & 0.02832 & cubic meter $\left(\mathrm{m}^{3}\right)$ \\
acre-foot $(\mathrm{acre}-\mathrm{ft})$ & 1,233 & cubic hectometer $\left(\mathrm{hm}^{3}\right)$ \\
\hline & 0.001233 & \\
\hline cubic foot per second $\left(\mathrm{ft}^{3} / \mathrm{s}\right)$ & Flow rate & cubic meter per second $\left(\mathrm{m}^{3} / \mathrm{s}\right)$ \\
\hline
\end{tabular}


Temperature in degrees Celsius $\left({ }^{\circ} \mathrm{C}\right)$ may be converted to degrees Fahrenheit $\left({ }^{\circ} \mathrm{F}\right)$ as follows:

${ }^{\circ} \mathrm{F}=\left(1.8 x^{\circ} \mathrm{C}\right)+32$

Temperature in degrees Fahrenheit $\left({ }^{\circ} \mathrm{F}\right)$ may be converted to degrees Celsius $\left({ }^{\circ} \mathrm{C}\right)$ as follows:

${ }^{\circ} \mathrm{C}=\left({ }^{\circ} \mathrm{F}-32\right) / 1.8$

Vertical coordinate information is referenced to the North American Vertical Datum of 1988 (NAVD 88), except where noted in text as National Geodetic Vertical Datum of 1929

(NGVD 29). In the study area, the NAVD 88 datum is 0.5 feet lower than the NGVD 29 datum, and consequently altitudes in NGVD 29 are 0.5 feet greater than the same altitudes referenced to NAVD 88.

Horizontal coordinate information is referenced to the North American Datum of 1983 (NAD 83).

Altitude and lake level, as used in this report, refer to distance above the vertical datum.

\title{
Abbreviations
}

\author{
DEM digital elevation model \\ DFIRM digital flood insurance rate map \\ FEMA Federal Emergency Management Agency \\ HWM high-water mark \\ MODIS moderate resolution imaging spectroradiometer \\ USGS U.S. Geological Survey
}





\title{
Assessment of the Spatial Extent and Height of Flooding in Lake Champlain During May 2011, Using Satellite Remote Sensing and Ground-Based Information
}

\author{
By David M. Bjerklie, Thomas J. Trombley, and Scott A. Olson
}

\section{Abstract}

Landsat 5 and moderate resolution imaging spectroradiometer satellite imagery were used to map the area of inundation of Lake Champlain, which forms part of the border between New York and Vermont, during May 2011. During this month, the lake's water levels were record high values not observed in the previous 150 years. Lake inundation area determined from the satellite imagery is correlated with lake stage measured at three U.S. Geological Survey lake level gages to provide estimates of lake area at different lake levels (stage/area rating) and also compared with the levels of the high-water marks (HWMs) located on the Vermont side of the lake. The rating developed from the imagery shows a somewhat different relation than a similar stage/area rating developed from a medium-resolution digital elevation model (DEM) of the region. According to the rating derived from the imagery, the lake surface area during the peak lake level increased by about 17 percent above the average or "normal" lake level. By using a comparable rating developed from the DEM, the increase above average is estimated to be about 12 percent. The northern part of the lake (north of Burlington) showed the largest amount of flooding. Based on intersecting the inundation maps with the medium-resolution DEM, lake levels were not uniform around the lake. This is also evident from the lake level gage measurements and HWMs. The gage data indicate differences up to 0.5 feet between the northern and southern end of the lake. Additionally, the gage data show day-to-day and intradaily variation of the same range ( 0.5 foot). The high-water mark observations show differences up to 2 feet around the lake, with the highest level generally along the south- and west-facing shorelines. The data suggest that during most of May 2011, water levels were slightly higher and less variable in the northern part of the lake. These phenomena may be caused by wind effects as well as proximity to major river inputs to the lake. The inundation areas generated from the imagery generally coincide with flood mapping as estimated by the Federal Emergency Management Agency (FEMA) and shown on its digital flood insurance rate maps. Where areas in the flood inundation map derived from the imagery and the FEMA estimated flooded areas differ substantially, this difference may be due to differences between the flood magnitude at the time of the image and the assumed flood condition used for the FEMA modeling and mapping, wind/storage effects not accounted for by the FEMA modeling, and the resolution of the image compared to the DEM used in the FEMA mapping.

\section{Introduction}

Lake Champlain lies in a broad valley between the Adirondack Mountains of New York and the Green Mountains of Vermont (fig. 1). The Lake Champlain Basin covers 8,234 square miles $\left(\mathrm{mi}^{2}\right)$ in New York, Vermont, and Quebec, Canada, with the lake occupying only 5.4 percent of the basin (approximately $440 \mathrm{mi}^{2}$ ). The lake extends 120 miles (mi) from Whitehall, N.Y., northward to the United StatesCanadian border where it outflows into the Richelieu River in Quebec, which flows into the St. Lawrence River and eventually into the Atlantic Ocean at the Gulf of St. Lawrence. The lake has a surface area of approximately $435 \mathrm{mi}^{2}$ when the lake surface lake level is at its mean value of 96.5 feet (ft; 29.5 meters [m]; Shanley and Denner, 1999) with $587 \mathrm{mi}$ of total shoreline (Lake Champlain Basin Program, 2002). The lake has three distinct regions: a narrow riverlike region at the southern end of the lake, a wide central region, and a wide northern region that includes several large islands. The largest rivers that flow into Lake Champlain include the Mississquoi, Lamoille, and Winooski Rivers and Otter Creek in Vermont and the Saranac, Ausable, La Chute (flowing from the outflow of Lake George into Lake Champlain), Poultney (flowing into the southern end of the lake), and Bouquet Rivers in New York. Lake Champlain was formed about 12,000 years ago as the last glacial period came to an end and the retreating glaciers left behind a large body of freshwater which included the Great Lakes, Lake Champlain, and much of the St. Lawrence River Valley (Lake Champlain Research Consortium, 2004). 


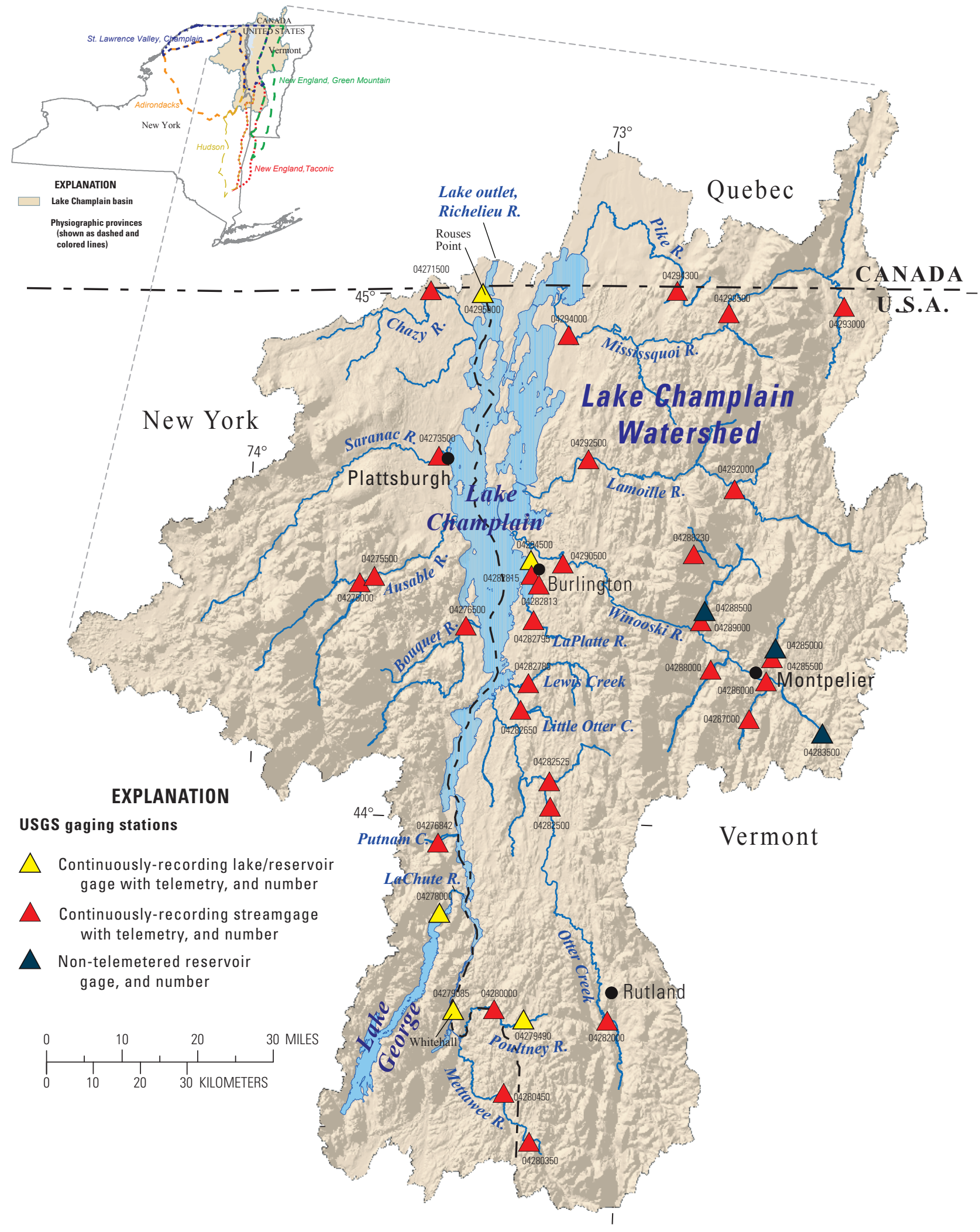

Figure 1. Lake Champlain Watershed and U.S. Geological Survey streamgages and lake/reservoir stage gages; from U.S. Geological Survey (2013a). 
Most of the lake tributaries are high-gradient streams which peak within 24 hours in response to precipitation or snowmelt. In most of the mountainous basin, a high percentage of the winter precipitation is stored in the snowpack.

Therefore, the dominant hydrologic event of the year is spring snowmelt, when nearly half of the annual streamflow typically occurs in a 6- to 8-week period (Shanley and Denner, 1999). Because of storage within the lake, the peak lake level lags the peak inflow by several days.

The Lake Champlain region experienced historic flooding during the spring and late summer of 2011 (Kiah and others, 2013). Beginning in late April through May 2011, historically high flood levels, resulting from melting snow and rainfall, were observed in Lake Champlain. During this period, rivers entering the lake were flowing at high discharges, especially on the Vermont side of the lake. However, only the Lamoille River gaged at East Georgia, Vt., and a few smaller rivers on the Vermont side had peak discharges at new record levels. Even though river inflows were generally not at new peak discharges, higher than average discharges were sustained over an extended period, which resulted in water levels in the lake being more than a foot above the highest observed level since the mid-1800s and caused substantial flooding of properties around the lake and downstream of the lake along the Richelieu River (which is formed at the outlet of the lake) in Quebec. Variable lake levels and shoreline erosion during the high water appear to have been exacerbated by wind-driven waves associated with local fetch as well as lake-wide seiche effects (standing oscillating wave with a long wavelength). These seiche events have been reported in the lake (Shanley and Denner, 1999) and are created by wind and atmospheric pressure changes.

The spring rainfall across the St. Lawrence Basin, in addition to a warm, saturated late spring snowpack, produced a major runoff event into Lake Champlain in April 2011. As previously mentioned, this caused extensive local flooding of streams and main-stem rivers tributary to Lake Champlain. As a result, Lake Champlain increased to a peak lake level of $102.8 \mathrm{ft}$ (referenced to the North American Vertical Datum of 1988, NAVD 88) as recorded at the Rouses Point, N.Y., gage (04295000) on May 6th with a daily mean lake level of $102.7 \mathrm{ft}$. At the Burlington, Vt., gage (04294500), the record stage was also set on May 6th with a peak stage of $102.8 \mathrm{ft}$ (NAVD 88) and a daily average of $102.7 \mathrm{ft}$. The peak stage recorded at the Whitehall, N.Y., gage (04279085) was recorded on May 9, 2011, with a lake level of $103.1 \mathrm{ft}$ (NAVD 88) and a daily mean of $102.6 \mathrm{ft}$. All of these lake levels exceed the previous maximum known lake level (since at least 1827) of approximately $101.6 \mathrm{ft}(102.1 \mathrm{ft}$ based on the National Geodetic Vertical Datum of 1929, NGVD 29) set in 1869 at Rouses Point, and $101.4 \mathrm{ft}$ (NAVD 88) for the period of record at the Burlington gage set in 1993 (Shanley and Denner, 1999). However, alterations to the outlet channel have caused a general rise in the lake level of about $0.15 \mathrm{~m}$ (0.5 ft) since the 1960s (Shanley and Denner, 1999). The peak lake level that occurred on May 7 has been estimated to have a less than 0.2-percent annual exceedance probability (greater than 500-year event) (Olson and Bent, 2013). The flood stage for the lake, as defined by the National Oceanographic and Atmospheric Administration (NOAA) National Weather Service is $99.5 \mathrm{ft}$ (NAVD 88; $100 \mathrm{ft}$ NGVD 29). The currently defined 1-percent annual exceedance probability (100-year) water level for the lake is $101.5 \mathrm{ft}$ (102.0 $\mathrm{ft}$ NGVD 29) and the 0.2 -percent annual exceedance probability (500-year) water level of $101.9 \mathrm{ft}$ (102.4 ft NGVD 29) published in the flood insurance study for Chittenden County, Vt. (Vermont Department of Environmental Conservation, n.d.)

Subsequent rainfall and runoff events kept Lake Champlain above $101.5 \mathrm{ft}$ for the entire month of May. Hundreds of lakeshore homes were inundated during this period. High winds resulted in wave heights in excess of $3 \mathrm{ft}$ (Lake Champlain Basin Program, 2013), which further exacerbated shoreline erosion and damage to structures along the lakeshore. Vermont declared a state of emergency as a result of the flooding on May 5, 2011. A presidential disaster declaration (declaration number DR-1995) was made on June 15, 2011. Lake Champlain was above flood stage for 67 consecutive days, reaching its peak stage on May 6, 2011.

Although the above-referenced gages on Lake Champlain recorded the peak stage at three locations on the lake, what are not fully documented and quantified are the differential lake-wide spatial variations in the lake level and areal extent of flooding caused by seiche and wind-driven wave action and other dynamic conditions resulting from river inflow and currents. This information is important for informing future mitigation and reconstruction decision-making efforts as well as for facilitating the identification and mapping of areas affected by this historical flood of record.

This study maps the flooded lake area and height of lake levels for Lake Champlain during the high water of May 2011, with a focus on the shoreline areas of Addison, Chittenden, Franklin, and Grand Isle Counties, Vt. Remote sensing information from Landsat 5 and moderate resolution imaging spectroradiometer (MODIS) imagery were used to map the areal extent of the flooded lake. The approach is similar to that recommended by Pan and others (2012). The flood extent is intersected with a $10-\mathrm{m}$ resolution digital elevation model (DEM; absolute vertical accuracy is 2.44-m root mean square error) available for the region (U.S. Geological Survey, n.d.). Because the high-resolution 3- to 1.6-m DEM is only available for the Vermont side of the lake and does not cover the entire lake shoreline, it was not used for analysis in this report.

\section{Study Objectives}

This study uses readily available remote sensing information to provide a lake-wide contiguous view of May 2011 historical peak flooding around the lake. Lake-wide remote sensing observations, along with high-water marks (HWMs) identified and surveyed in the field and lake levels measured at fixed recording stations, provide a means to understand 
variations in lake levels and extent of flooding across the lake. The U.S. Geological Survey (USGS) developed a scope of work to address the following general objectives:

- Document the 2011 event, including the inundated area and the variability of the peak flood elevations around the lake.

- Evaluate accuracy of current flood mapping by using remote imagery of the May 2011 event, and compare observed flood with location and elevation of fieldidentified HWMs.

- Use satellite imagery to develop independent stage/lake area ratings that could be helpful for lake modeling studies and flood-management applications.

- Provide supporting information for future studies currently being developed.

\section{Purpose and Scope}

This report provides information and data describing the extent of flooding in and around Lake Champlain during the historic high water of May 2011. Existing data documenting the flooding are compiled and summarized, and Landsat imagery is used to map the extent of flooding that occurred around the lake. The report has information about the weather conditions in the Lake Champlain region during months leading up to May 2011. Details of the remote-sensing and ground-based methods used to assess lake levels are presented. Data tables are included that detail high-water marks and satellite imagery used to determine lake level (stage) and lake area. Assessment results include a calibrated stage/image lake-area rating and DEM lake-area rating. The spatial extent and height of the May 2011 flooding are described together with the results from lake level gages that document the daily variations in flood levels.

\section{Weather and Climatic Conditions During Winter and Spring, 2010-2011}

The extreme lake flooding experienced during May 2011 resulted from the weather and hydrologic conditions that preceded it during the winter and spring of 2010-2011. A detailed discussion of the climate and weather conditions leading up to and during the flooding event can be found at National Oceanic and Atmospheric Administration (2012). In summary, winter weather conditions produced heavy snowpack in the Adirondack Mountains to the west and the Green Mountains to the east of Lake Champlain. A series of melt and rain-on-snow events filled the lake during March, April, and May 2011. During the winter of 2010-2011, Burlington, Vt., received 128.4 inches (in.) of snow, which is among the top ten highest recorded snowfalls for the city.
Seasonal snowfall totals measured atop Mount Mansfield were 252.7 in. This above-normal snowfall created snow depths in the mountains between 4 and $8 \mathrm{ft}$, with total water equivalent values between 10 and 20 in.

The snow water equivalent held within the snowpack on March 15, 2011, was between 15 and 25 in. of water in the northern Adirondack Mountains in New York and between 20 and 30 in. in the central and northern Green Mountains in Vermont (National Oceanic and Atmospheric Administration, 2012). Meanwhile, the snowpack held between 4 and 8 in. of water across the lower altitudes of the Champlain Valley.

During the month of May, above-normal rainfall occurred with over 24 in. of rain falling across the mountains of central and northern Vermont and 28.29 in. falling atop Mount Mansfield, Vt. In addition, Burlington, Vt., received 19.84 in. of rainfall during this period. The combination of abovenormal rainfall and snowmelt from record snow accumulations in the watershed surrounding the lake drove (were the major factors causing) the historic and long-duration flood event on Lake Champlain.

In addition to the prevailing westerly (coming from the west) winds across the lake, several strong southerly (coming from the south) wind events on April 23 and May 5, 2011, produced significant wave action and additional storm-surge flooding along the southern exposed shorelines. Several northerly (coming from the north) wind events also occurred, causing additional surge flooding on the northern exposed shorelines, in separate events on May 9 and June 1, 2011. The wind events contributed to widely varying water levels across the lake, caused by wind-driven waves and seiche effects, and water piling up along shorelines caused by the prevailing wind.

\section{Data and Methods}

The data and information used for this study were derived and obtained from satellite remote sensing imagery, groundbased HWM identification, and lake and river gages. These data were used in conjunction with existing topographic data from a DEM for the land around the lake and for comparison with existing flood mapping. The satellite imagery enables indirect observation of the entire lake at a given time during the flood event, and the HWMs and gage data provide specific-point information that indicates the spatial distribution of high water around the lake over the period of flooding. River inflow data were also compiled for the period of flooding and correlated with lake water-level dynamics.

The satellite imagery provides observations of inundated areas from all open water sources, including rivers, surface runoff and ponding, and flooded areas that have varying lake levels. This observational tool provides more information than assuming a single water surface lake level across the lake. The HWMs similarly mark differential peak lake levels that are related to the flooding and reflect varying lake levels that 
might be caused by wind and waves, river inflow, and other dynamic effects on the lake. Thus, these observational data provide a look at the reality of the flood in terms of the extent and height during May 2011. These data mapped along with the DEM indicate the spatial variation and extent of the high water during the flooding and provide a valuable comparison with the existing flood insurance mapping, indicating where existing mapping does not account for dynamic lake interactions with river inflow and wind.

The remote sensing information can also provide:

(1) independent verification of water levels around the lake in the absence of comprehensive ground data, both historically and spatially, (2) observational verification of models, and (3) observations of sediment plumes in the lake. This study uses publically available imagery and software, such that the study can serve to demonstrate their application for other studies. The publically available imagery used was from Landsat (http://landsat.usgs.gov) and MODIS (http://modis. gsfc.nasa.gov/).

\section{Lake Stage Records and River Inflows During Late April Through Early June 2011}

The USGS maintains three continuously recording lake stage sensors with telemetry on Lake Champlain, including gages at Whitehall and Rouses Point, N.Y., and Burlington, Vt. The Rouses Point gage is located at the lake outlet and head of the Richelieu River and has records extending back to 1871 . The gage records extend back to 1907, and records from the Whitehall gage extend back to 1998. Hydrographs of Lake Champlain water level during the height of the flooding from April 28 through June 15, 2011, for all three gages are shown on figures 2 and 3. Daily mean lake levels recorded at Burlington, Vt. (gage 04294500), from April to June 2011 are shown in figure 2. Continuous lake levels (plotted at 15-minute intervals, also from April to June 2011) through the period of flooding for the Burlington gage, the Whitehall gage (04279085), and the Rouses Point gage (04295000), are shown in figure 3 . The daily mean water level in the lake fluctuated from 100 to $102.7 \mathrm{ft}$ during May, remaining above the National Weather Service flood stage of $99.5 \mathrm{ft}$ from early April to mid-June, and remaining above the highest known historic lake level of $101.6 \mathrm{ft}$ (since recordkeeping began in 1827) and maximum measured lake level at the Burlington gage of $101.4 \mathrm{ft}$ (1993) for most of May. The 15-minute lake levels for all three lake level gages (fig. 3 ) show the subdaily variation. The data show that daily variation can be as much as $0.4 \mathrm{ft}$, with the greatest fluctuation seen at Whitehall, located at the narrow southern end of the lake. The peak 15-minute lake levels were higher than the daily mean at all three stations. At Whitehall, the daily mean peak was $102.6 \mathrm{ft}$ and the 15-minute peak was $103.1 \mathrm{ft}$, at Rouses Point the daily mean was $102.6 \mathrm{ft}$ and the 15 -minute peak was $102.7 \mathrm{ft}$, and at Burlington the daily mean peak was $102.7 \mathrm{ft}$ and the 15-minute peak was $102.8 \mathrm{ft}$.
A key question arises that is important for understanding the mechanisms that drive water-level variation in the lake, with important implications for forecasting lake levels in the future. This question is how much of the water height observed at any location is caused by wind effects and how much by inflow and storage in the lake? Based on the gage data, the lake level variation over the flooding period was approximately $3 \mathrm{ft}$, with daily mean changes of greater than $0.5 \mathrm{ft}$, and instantaneous variation as high as $0.4 \mathrm{ft}$. Given the large storage volume in the lake, this relatively rapid fluctuation, particularly during the day, may reflect wind effects overlain on a more general rise caused by inflow.

River inflows to Lake Champlain for the most significant gaged rivers are shown on figure 4 and include the Mississquoi River at Swanton, Vt. (gage 04294000); the Lamoille River at East Georgia, Vt. (gage 04292500); the Winooski River at Essex Junction, Vt. (gage 04290500); Otter Creek at Middlebury, Vt. (gage 04282500); the Saranac River at Plattsburgh, N.Y. (gage 04273500); the Ausable River near Au Sable Forks, N.Y. (gage 04275500); the Poultney River near Fairhaven, Vt. (gage 04280000); and the Bouquet River at Willsboro, N.Y. (gage 04276500). (Gaging station locations are shown on fig. 1.) Outflow in the Richelieu River (Environment Canada gage 020J007) was derived from estimates at the weir located at Fryers Dam, Quebec. In general, all of the river inputs show similar timing of high and low flows, indicating similar snowmelt and rainfall timing occurring from the east (Vermont side) and west (New York side) of the lake. The largest peak inflows occurred from the Vermont side, and in general the peak lake levels occurred around two days after the peak inflows.

\section{Satellite Imagery}

The Landsat imagery included Landsat 5 with 30-m resolution (bands 1-5 and 7) and 120-m resolution (band 6), revisiting the same ground track with a nearly full image of the lake observed every 16 days. The Landsat image footprint did not cover the entire lake. The lower part near Whitehall, which includes approximately 10 percent of the lake area, was not included in the image. The missing lake area was estimated from the moderate resolution imaging spectroradiometer (MODIS) imagery for this study. Two mostly cloud-free Landsat images were available during the study - from May 11, 2011, near the height of the flood, and from July 14, 2011, at a lower lake level (table 1). These images are shown with bands 3, 4, and 5 in figure 5. The AQUA MODIS image for May 11, 2011, is compared with the Landsat 5 image for the same date in figure 6 . Note the resolution difference (30-m Landsat and 250-m MODIS) and the different cloud cover caused by different observation times during the day. Only Landsat 5 imagery was used in the analysis. Although Landsat 7 imagery was available for the flood period, defects in the scan line detector (SLC; U.S. Geological Survey, 2013b) in the image not providing continuous coverage over the observation 


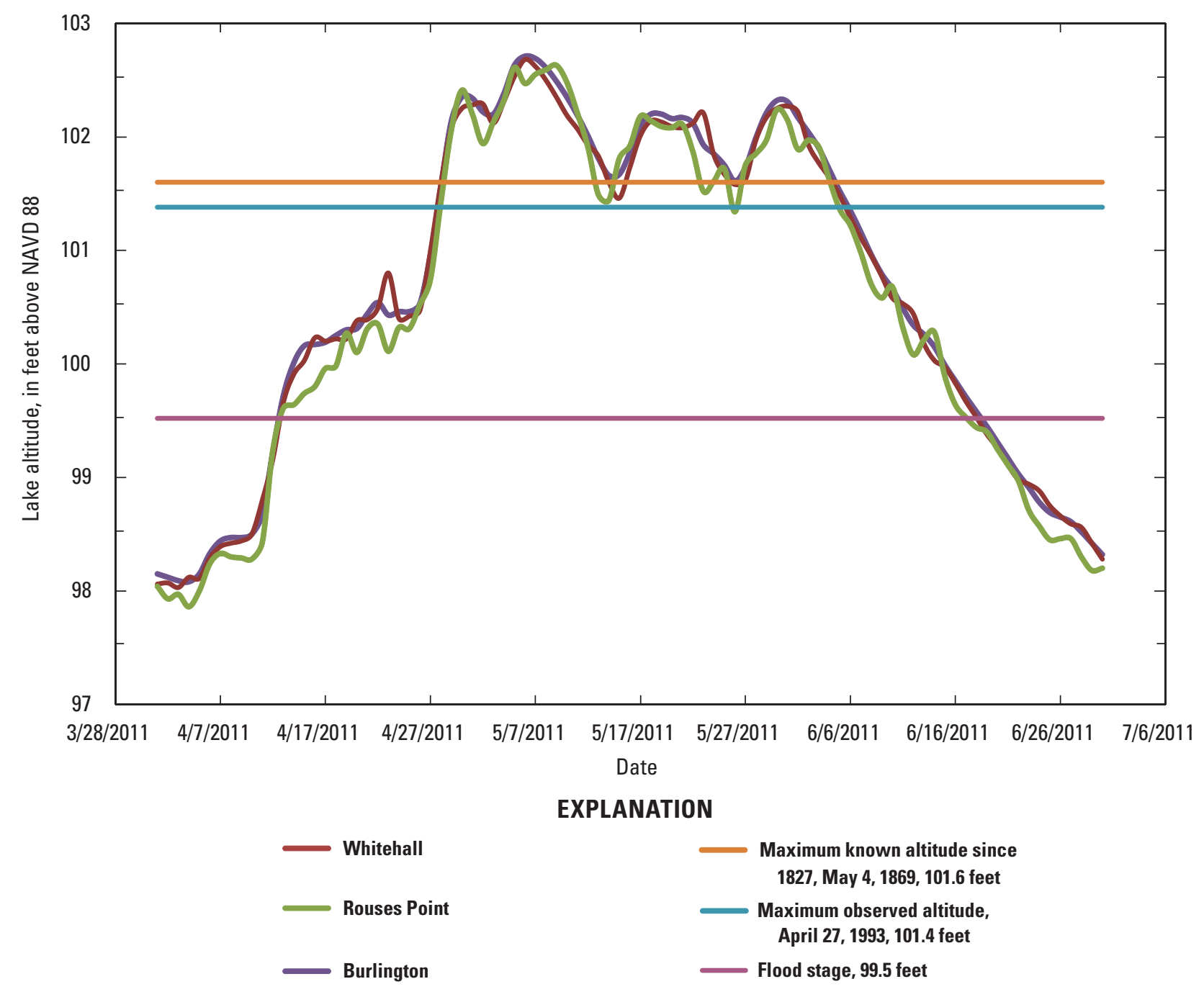

Figure 2. Daily mean lake level at the Burlington, Vermont, Rouses Point, and Whitehall, New York, gages from April to June 2011; from National Oceanic and Atmospheric Administration (2012).

area. As such, the Landsat 7 imagery was acquired and reviewed but not used in the analysis.

The MODIS imagery has two bands at 250-m resolution and five bands at 500-m resolution. MODIS has a daily revisit period. Bands 1 (red) and 2 (near infrared) with 250-m resolution were used in the analysis. The MODIS instrument is carried on the TERRA (MOD09) and AQUA (MYD09) satellites, where an observation of the lake is acquired two times each day, once in the morning (TERRA) and once in the afternoon (AQUA). The MODIS images used in the analysis are listed on table 1 and include those that were cloud free or primarily cloud free for the lake area.
The remote sensing imagery observes the entire lake at each pass (except where noted above for Landsat); thus the remote sensing aspect of the study encompasses both the eastern (Vermont side) and western (New York side) shore of the lake. Image analysis for Landsat and MODIS was completed by using MultiSpec (https://engineering.purdue. edu/ biehl/MultiSpec/index.html), a publically available software package which enables supervised analysis of three bands simultaneously. The software uses the threeband spectral signature to distinguish water and nonwater. The area of analysis included the lake and an approximately 0.6-mi (1 km)-wide zone (mask) around the lake perimeter 


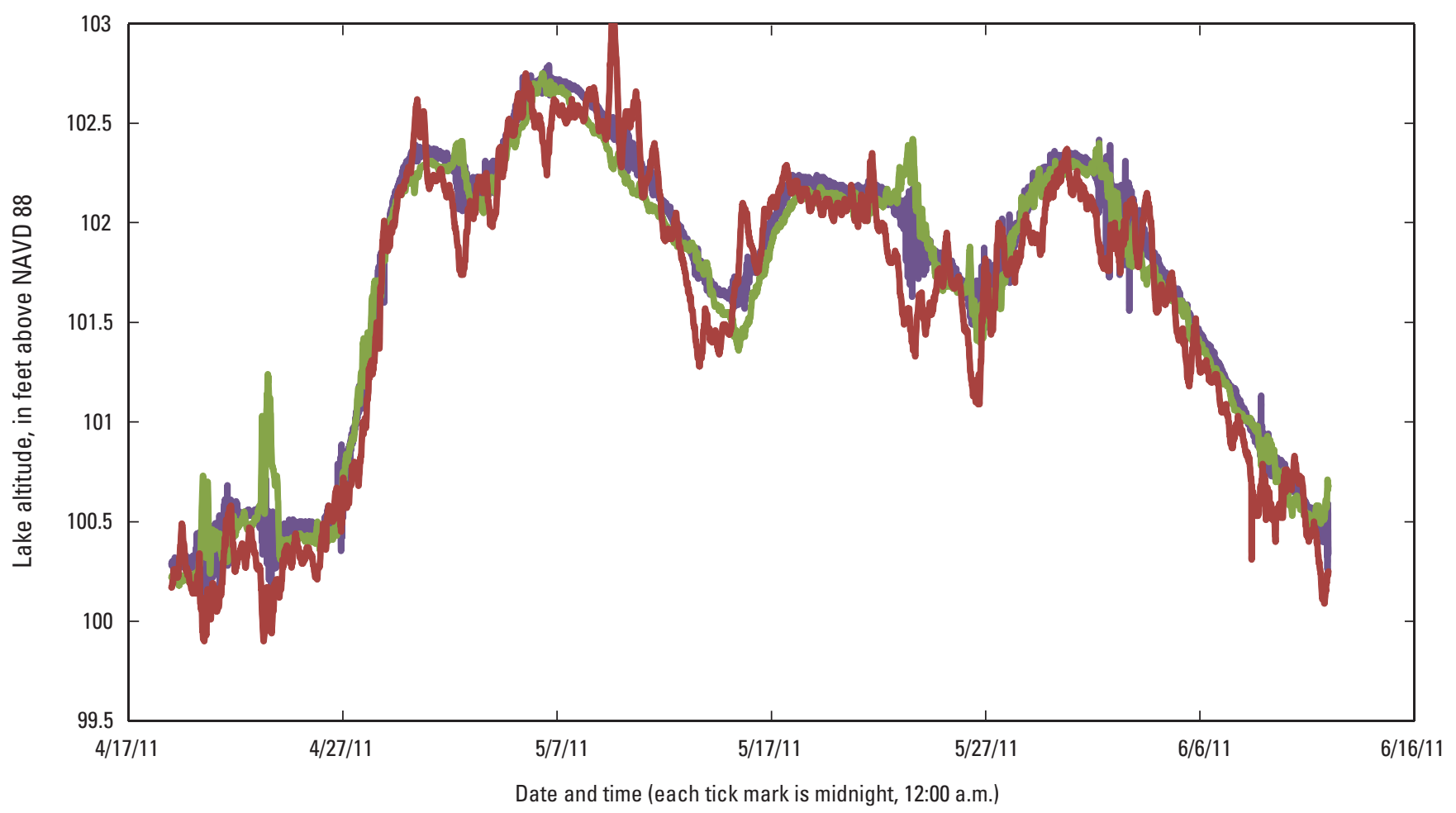

EXPLANATION

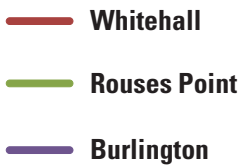

Figure 3. 15-minute lake level at the Rouses Point, New York, Burlington, Vermont, and Whitehall, N.Y., gages for the period from April to June 2011.

(shoreline). Each image was calibrated independently to identify water (see following paragraph), and then MultiSpec identified and calculated the total water-surface area within the masked river reach. Areas of nonconnected water that may have been within the unmasked area were removed by inspection of the image after the processing. The Landsat images used in the analysis are shown on table 1.

On the basis of visual inspection of the images, and considering the band characteristics, Landsat bands 4, 5, and 7 were found to provide the best differentiation and identification of water from land for the Landsat 5 images. The MultiSpec software was used to distinguish between water and nonwater and was calibrated visually by selecting representative areas of the image for classification. The Landsat image analysis proceeded by supervised selection of seven water classes and two land classes to capture the variation in spectral characteristics of each target (land or water) - the land target classification includes forest, agriculture, and cloud shadows; and the water target classification includes deep, shallow, near shore, upper, middle, center lake areas, and water with sediment. Selecting different classes for each target accounts for angle of light, depth, and reflectance differences across the lake. Similarly, the MODIS image analysis used both bands and included five water classes and two land classes to characterize the water and non-water targets.

Clouds were not included in water classes; thus clouds were always identified with land. The May 11 Landsat 5 image included some clouds in the northeastern part of the lake, and in this area the MODIS image for that date was used to fill in the minor cloud cover. Areas of cloud shadows appearing in the image were consistently identified as water by MultiSpec; these were nominally excluded by masking the lake. 
A

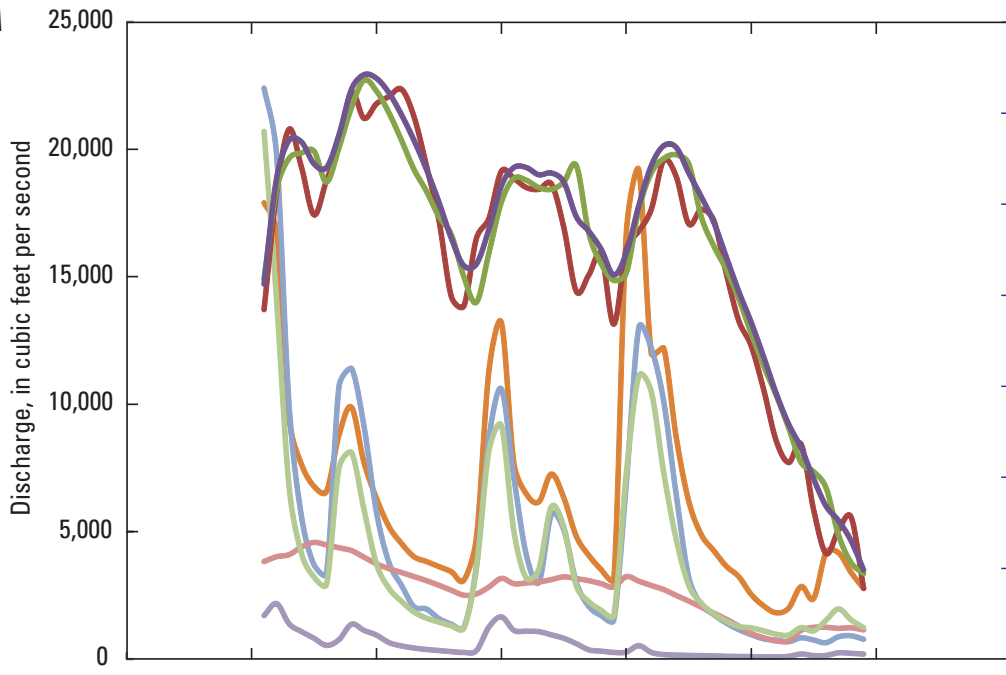

B

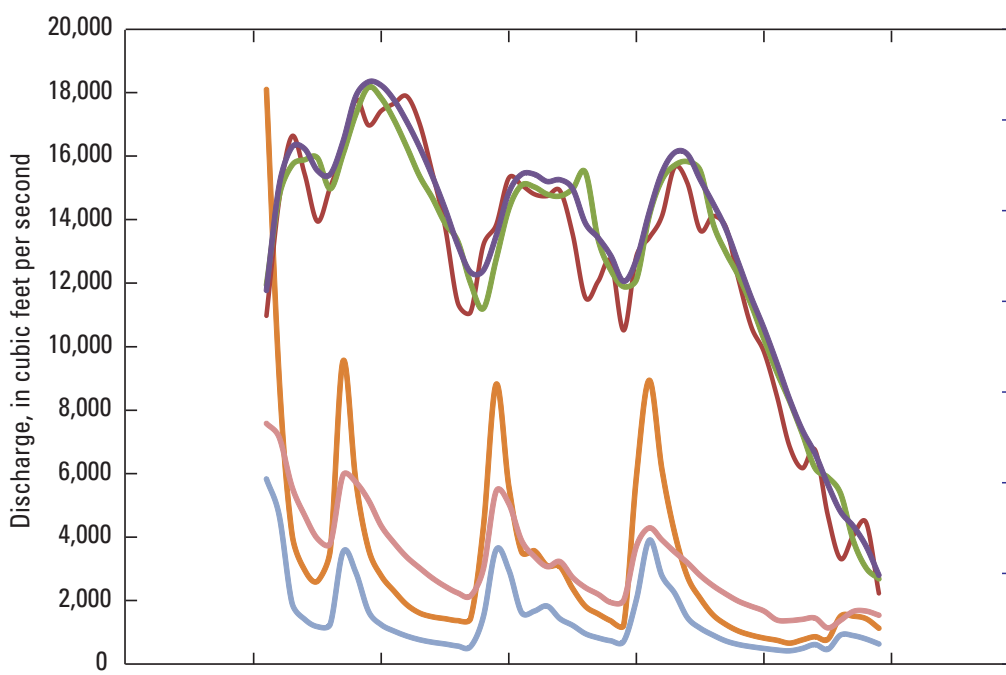

C

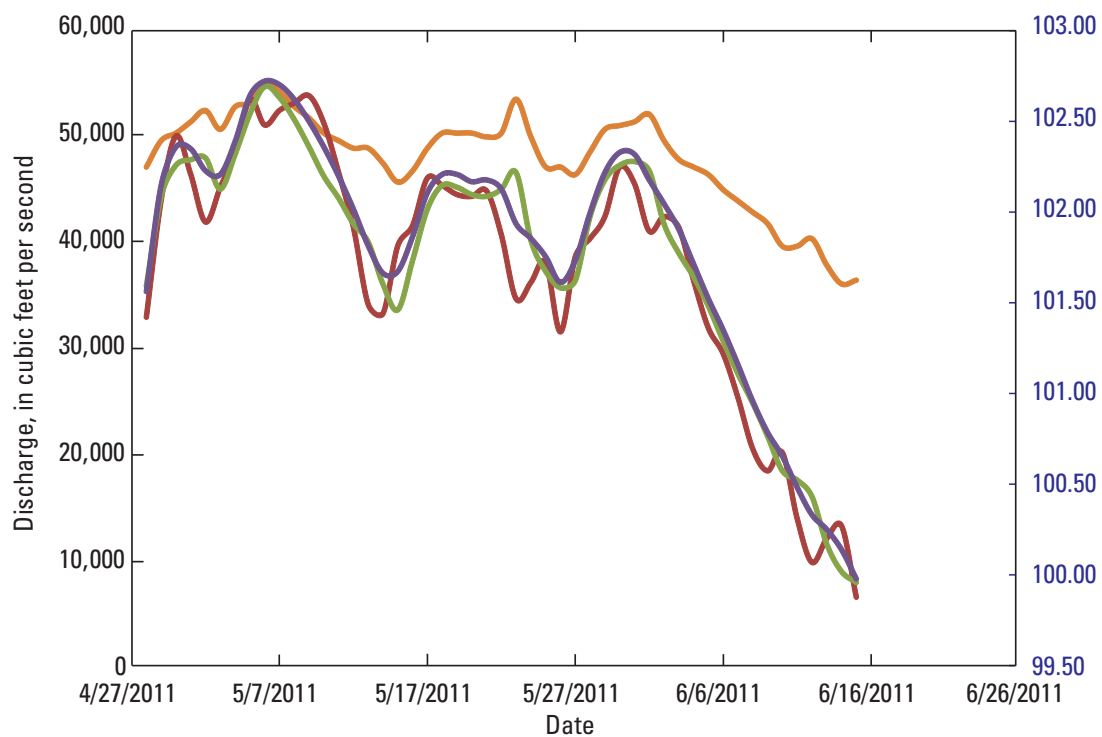

103.00

102.50

102.00

101.00

100.50

100.00

99.50

103.00

102.50

102.00

101.50

101.00

100.50

100.00

99.50

03.00

\section{EXPLANATION}

Lake outflow to Canada, in

cubic feet per second

$\infty$ - Richelieu River, $\mathrm{ft}^{3} / \mathrm{s}$

Lake gages, altitude in feet

z - Whitehall

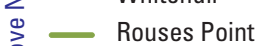

— Burlington

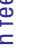

$\stackrel{0}{\frac{0}{0}}$

Inflow from Vermont rivers, in

Winooski River $\mathrm{ft}^{3} / \mathrm{s}$

Missisquoi River, $\mathrm{ft}^{3} / \mathrm{s}$

Lamoille River, $\mathrm{ft}^{3} / \mathrm{s}$

- Poultney River, $\mathrm{ft}^{3} / \mathrm{s}$

\section{EXPLANATION}

from New York rivers, in

Ausable River, $\mathrm{ft}^{3} /$

Bouquet River, $\mathrm{ft}^{3} / \mathrm{s}$

Whitehall

Rouses Point

Burlington

Figure 4. Daily mean river inflows to Lake Champlain measured at U.S. Geological Survey streamgages, daily mean outflow from the lake in the Richelieu River measured at Fryers Dam, and daily mean lake levels measured at Rouses Point, New York, Burlington, Vermont, and Whitehall, N.Y., between April 28 and June 15, 2011. A, the inflow hydrographs for rivers in Vermont and the lake levels; $B$, the inflow hydrographs for rivers in New York and the lake levels; and $C$, the outflow hydrograph for the Richelieu River and the lake levels. 
Table 1. Landsat and moderate resolution imaging spectroradiometer (MODIS) imagery available for flood period.

[TERRA is a satellite in descending orbit, crosses the equator at 10:30 a.m., and observes Lake Champlain 10-15 minutes earlier (approximately 10:15 a.m.) daily. AQUA is a satellite in ascending orbit, crosses the equator at 1:30 p.m., and observes Lake Champlain 10 to 15 minutes later (approximately 1:45 p.m.) daily. MODIS, moderate resolution imaging spectroradiometer; na, not available]

\begin{tabular}{lccll}
\hline \multicolumn{1}{c}{ Date } & Landsat 5 & Landsat 7 & MODIS TERRA & MODIS AQUA \\
\hline $4 / 30 / 2011$ & & Mostly cloud free visibility & \\
$5 / 1 / 2011$ & na & na & Cloud free & Cloud free \\
$5 / 7 / 2011$ & na & na & Cloud free & Partly cloudy \\
$5 / 8 / 2011$ & na & na & Partly cloudy & Partly cloudy \\
$5 / 9 / 2011$ & na & na & Cloudy & Partly cloudy \\
$5 / 10 / 2011$ & na & na & Cloudy & Partly cloudy \\
$5 / 11 / 2011$ & na & na & Cloud free & Cloud free \\
$5 / 12 / 2011$ & na & Cloud free & Cloud free \\
$5 / 19 / 2011$ & na & na & Cloud free & Cloud free \\
$5 / 25 / 2011$ & na & Partly cloudy & Partly cloudy & Partly cloudy \\
$5 / 30 / 2011$ & na & na & Partly cloudy & Cloud free \\
$5 / 31 / 2011$ & na & na & Cloud free & Cloud free \\
$6 / 1 / 2011$ & na & na & Partly cloudy & Partly cloudy \\
$6 / 3 / 2011$ & na & na & Partly cloudy & Some clouds \\
$6 / 4 / 2011$ & na & Cloud free & Partly cloudy & Cloud free \\
$7 / 14 / 2011$ & Cloud free & Partly cloudy & Cloudy & Partly cloudy \\
\hline $7 / 3 / 2010$ & & na & Cloud free & Partly cloudy \\
$8 / 28 / 2007$ & na & Cloud free & Cloud free \\
\hline
\end{tabular}

\section{Topography and Ground Level Data-Digital Elevation Models}

Two digital elevation model (DEM) datasets of topography are currently available for the lake, including a 10-m (horizontal resolution) USGS DEM available for the entire lake area and a 1.6- to 3.0-m horizontal resolution DEM available for Chittenden and Addison Counties, Vt. However, as mentioned previously, the higher resolution 1.6to 3.0-m DEM was not used because it did not encompass the entire shoreline of the lake. Additionally, the higher resolution DEMs were not completely compatible with each other, posing interpretive problems, and the resolution of the Landsat imagery $(30-\mathrm{m})$ is such that the difference between the $10-\mathrm{m}$ and the higher resolution 1.6- to 3.0-m resolution did not improve the comparative analysis with Landsat. The higher resolution DEM for Chittenden and Addison Counties has been used to develop lake level maps for those parts of the lake shoreline in these counties (National Oceanic and Atmospheric Administration, n.d.) but is not available at present for any other part of the lake. However it is anticipated that future light detection and ranging (lidar) missions will be flown and the higher resolution DEM will eventually be available for the entire lake.

\section{High-Water Marks}

The USGS flagged high-water marks (HWMs) in the Lake Champlain watershed during the summer and fall of 2011 (Medalie and Olson, 2013). The HWMs were identified in the field from debris lines and identified marks on structures and other semipermanent features along the lakeshore communities of Addison, Chittenden, Franklin, and Grand Isle Counties, Vt. Many of these marks were identified and later surveyed to obtain lake level and position. The marks were identified by field inspection and interviews with residents and local/state emergency management officials. After the HWMs were flagged, the HWMs were surveyed with global positioning system (GPS) survey-grade equipment to establish the horizontal position (latitude/longitude) and lake level referenced to the North American Vertical Datum of 1988 (NAVD 88). The HWM literally marks the maximum level 


\section{A. Landsat 5 image, May 11, 2011}
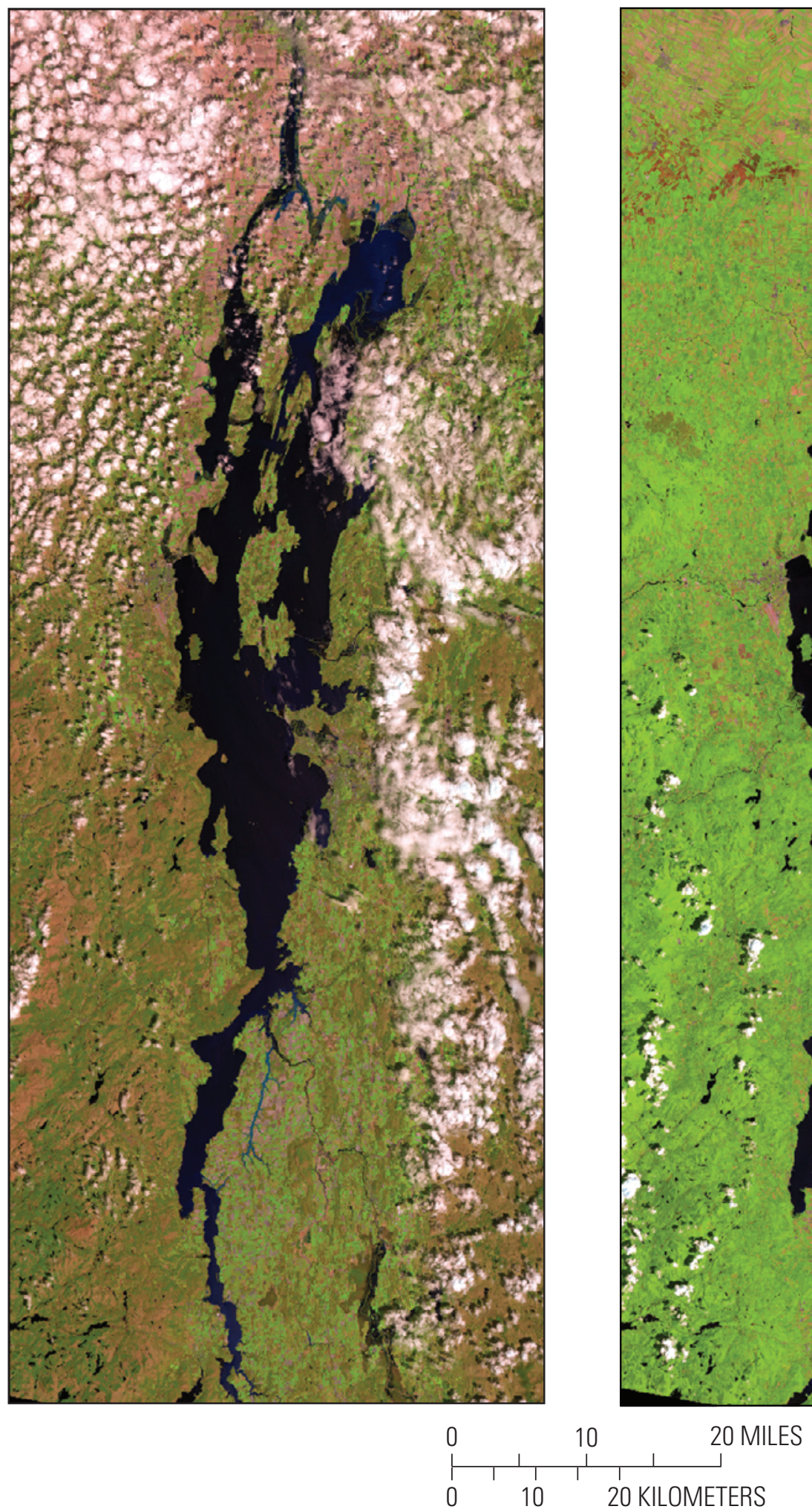

\section{B. Landsat 5 image, July 14, 2011}

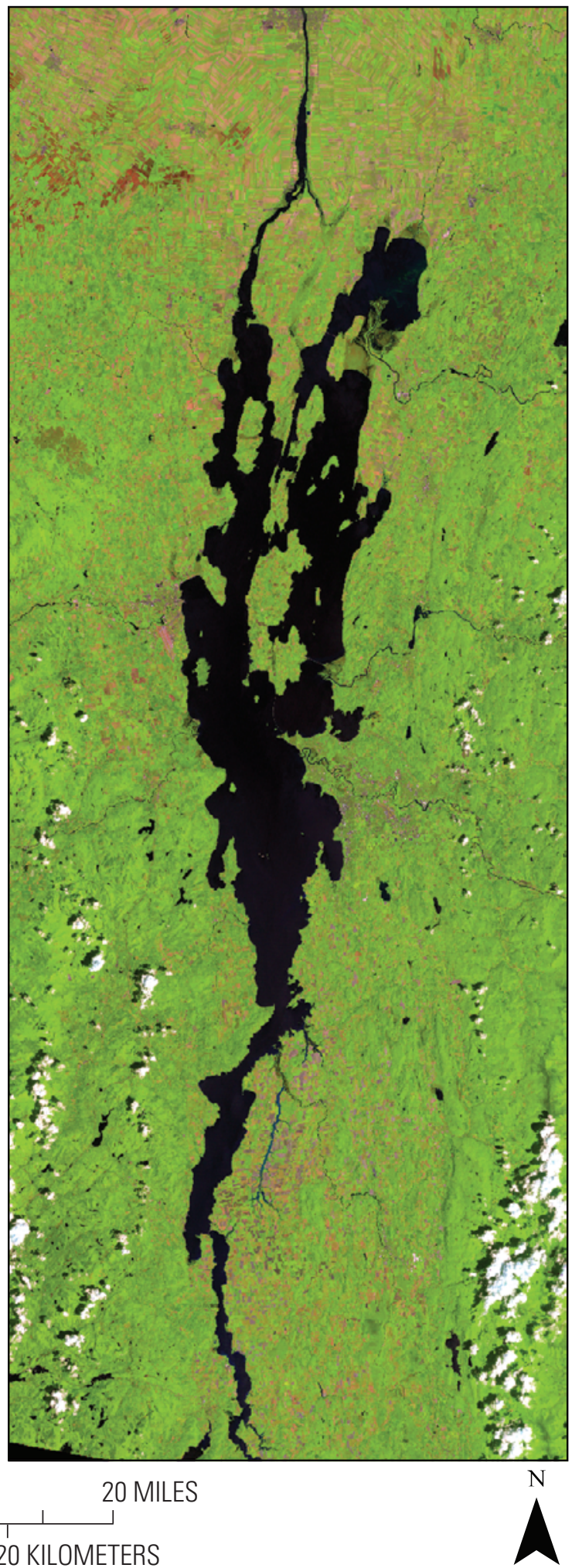

Figure 5. Landsat 5 image (bands 3, 4 and 5) of Lake Champlain. A, May 11, 2011, and B, July 14, 2011. 


\section{A. Landsat 5 image, May 11, 2011}
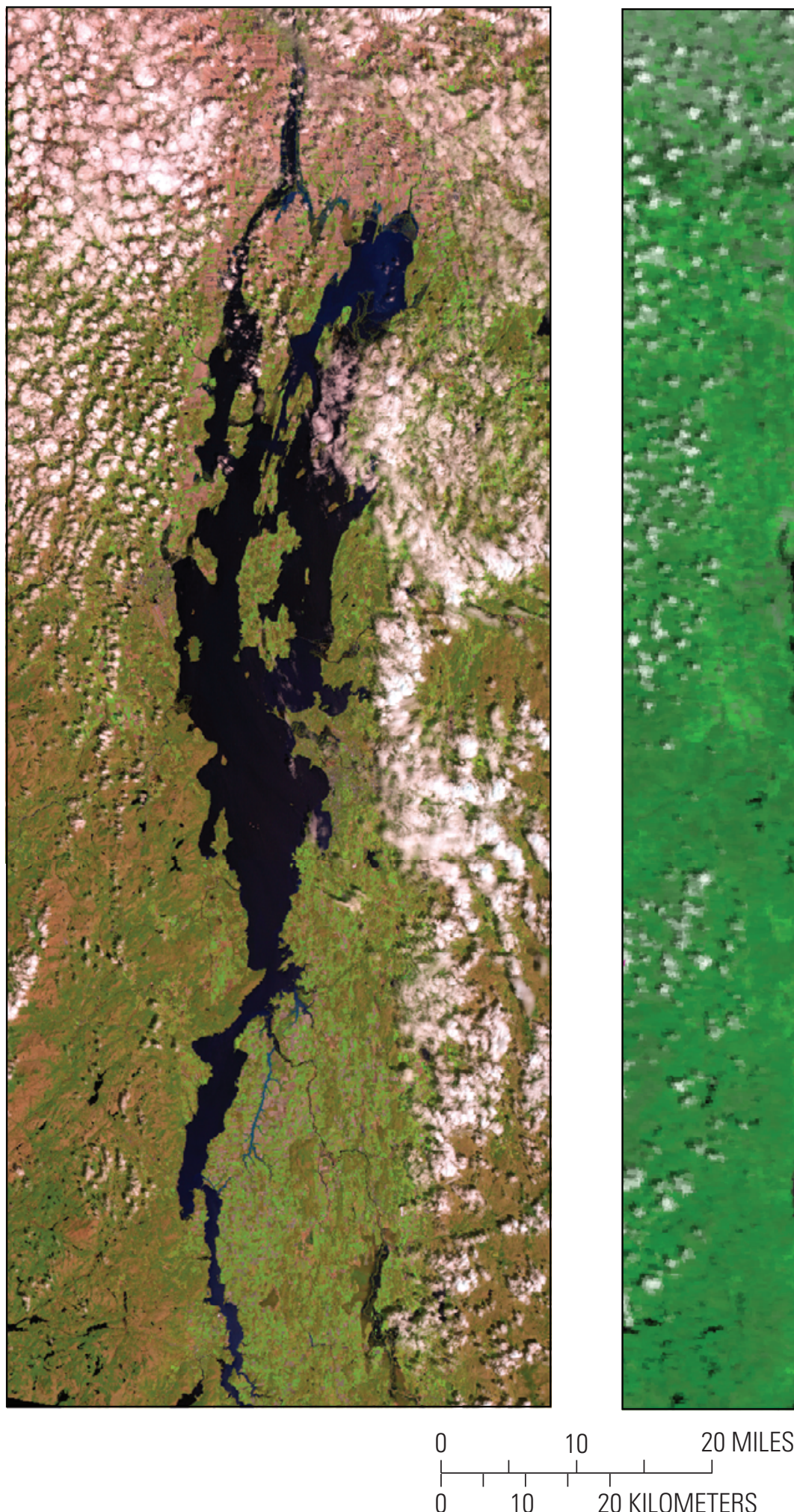

\section{B. MODIS image, May 11, 2011}

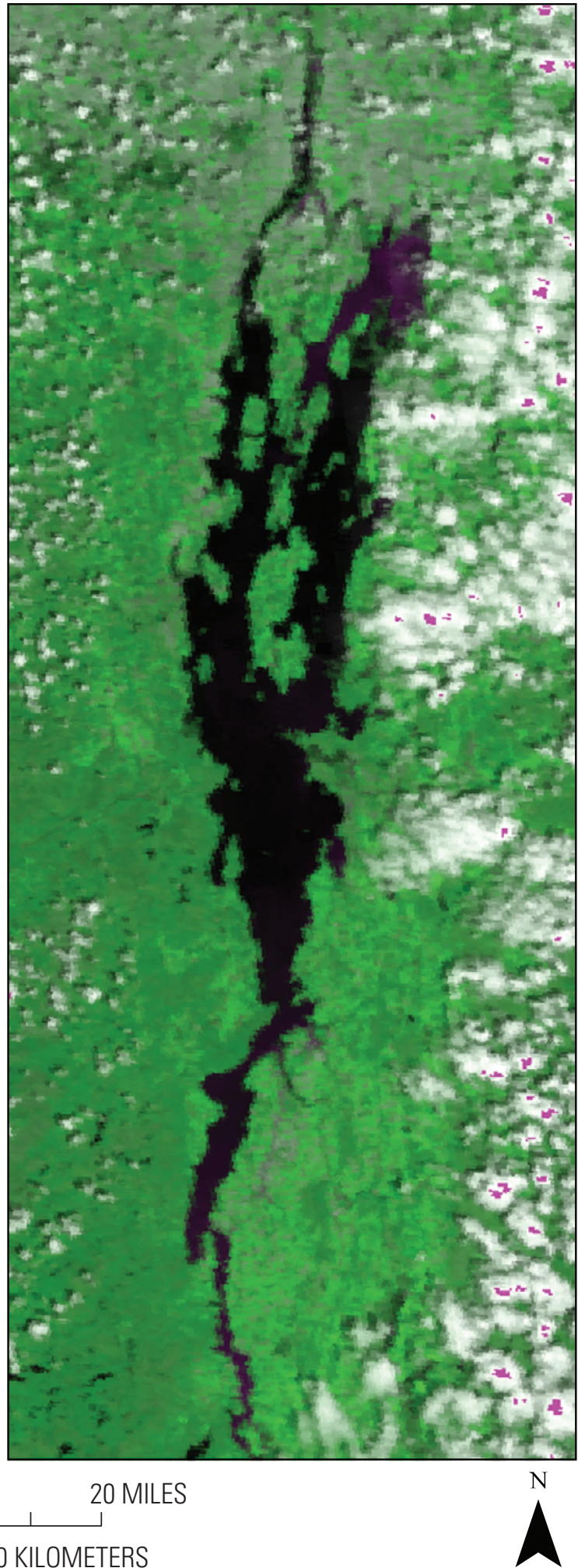

Figure 6. Landsat 5 and moderate resolution imaging spectroradiometer (MODIS) images of Lake Champlain. $A$, Landsat 5, May 11, 2011, and B, AQUA MODIS, May 11, 2011. Note the differences in cloud cover and resolution. 
that could be identified, and reflects the general high water in the lake as well as other effects that cannot be distinguished, including wind-driven seiche and higher water levels at and upstream of the mouths of rivers caused by river inflows and backwater effects. Those HWMs that were associated with the Vermont side of Lake Champlain during the subject flood are listed in table 2 .

\section{Analysis of Combined Data}

The Landsat and MODIS images that were available and which were primarily cloud free during the flood period, along with a number of images from before and after the flood, were analyzed with MultiSpec within the mask around the lakeshore to determine the lake surface area, including the inundation (flooded) area around the lake. The analysis results are shown on table 3. The lakeshore mask was used to assist in excluding smaller lakes, ponds, and flooded areas not associated with the lake itself. Landsat images, because of their moderate resolution, were used to correct the coarser resolution MODIS-derived lake surface and inundation area to construct a corrected lake stage and area rating curve that was compared with a stage/surface area rating derived from the 10-m DEM (table 4 and fig. 7). This was done by first developing a relation between the Landsat- and MODIS-derived lake surface area for coincident dates and then using the relation to correct the MODIS lake surface area estimate. The MODIS surface area was typically smaller than the Landsat estimate in large part because of the coarser resolution (250-m as opposed to $30-\mathrm{m}$ ), which missed areas of water along the shoreline. Subsequently, a best fit power relation was fit to the MODIS lake surface estimates to derive a lake stage/surface area rating. The rating developed from the imagery shows a different relation than the rating developed from a medium-resolution 10-m DEM of the region, indicating the need for a rating developed from the higher resolution DEM currently available for Chittenden and Addison Counties, Vt. (http://www.erh.noaa. gov/btv//html/hydro/inundation/inundation.html), data for the entire lake. The image-derived rating is more linear than the DEM-derived rating. It is interesting to note that the difference between the DEM-derived rating and the image-derived rating seen here shows characteristics similar to the same comparison shown by Pan and others (2012) for a part of Lake Champlain.

The distribution of HWMs and flooded areas developed from the imagery are intersected with the 10-m DEM for the lake and are shown on figure 8. The intersection of the DEM with the inundated area from the imagery provides a means to estimate the height of the inundated area around the lake shoreline. The digital flood insurance rate map (DFIRM) boundaries for Chittenden County, Vt., are also shown on figure 8. The areas of highest water levels determined from the imagery - as intersected with 10-m DEM - show the highest water levels near river mouths and along the eastern shoreline in the northern and central part of the lake where the lake is widest and offers the longest wind fetch. The HWMs show a similar pattern, with the highest levels along the eastern shoreline and in the northern part of the lake and the lowest levels in protected areas on the western shorelines.

\section{Spatial Extent and Height of Flooding During May 2011}

The flooded area identified from the Landsat 5 May 11 image had a mean lake level near $102.2 \mathrm{ft}$, which is slightly less than the peak level that occurred on May 7 and would be expected to have an exceedance probability less than the 500 -year event but greater than the value for the 100-year event used to construct the DFIRM (102 ft). Thus, the flooded area shown on figure 8 can provide a reference as to the expected flooded area for the 100-year event and greater. According to the rating derived from the imagery, the lake surface area during the peak lake level increased by about 17 percent above the average or "normal" lake level (increasing from approximately 440 to $513 \mathrm{mi}^{2}$ ). By using a comparable rating developed from the digital elevation model (DEM), the increase above average is estimated to be about 12 percent (increasing from approximately 467 to $525 \mathrm{mi}^{2}$ ).

The northern part of the lake, north of Burlington, experienced the largest amount of flood inundation, particularly in the river deltas of the Mississquoi, Winooski, and Lamoille Rivers, as well as the shoreline of Mississquoi Bay, the Lake Champlain Islands, and the Richelieu River. The May 11 Landsat 5 image shows several areas that differ from the 100-year flood zones identified from the DFIRM boundaries but on the whole shows consistency between flood boundaries and areas that were observed to be flooded. Areas observed to be flooded that were outside of the DFIRM boundary were in low-lying areas and near river mouths (fig. 8). The data also show variation of water levels around the lake with patterns suggesting wind effects. The discrepancies with the currently mapped floodplain boundaries indicate the need for hydrographers to update these boundaries by using methods that can account for local dynamics that affect water levels; the current methods do not make any adjustment for local dynamics.

\section{Water-Level Variations Across Lake Champlain During May 2011}

Gage levels at Rouses Point, Burlington, and Whitehall substantiate the differences in lake levels in Lake Champlain. The 15-minute recorded water levels at the three gages from April 19 to June 11, 2011, show that the daily mean lake water level was higher at Burlington than at Whitehall (by about $0.1 \mathrm{ft}$, mean difference of $0.085 \mathrm{ft}$ ) and higher at Burlington than at Rouses Point (also by about $0.1 \mathrm{ft}$, mean difference of $0.068 \mathrm{ft}$ ). The daily mean lake water-level difference 


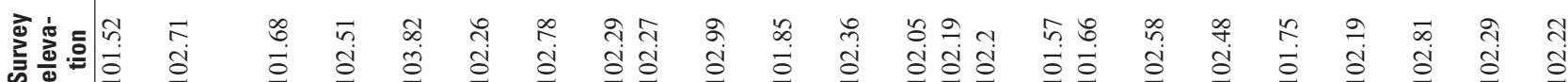

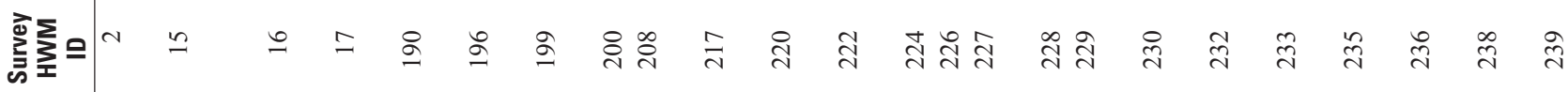

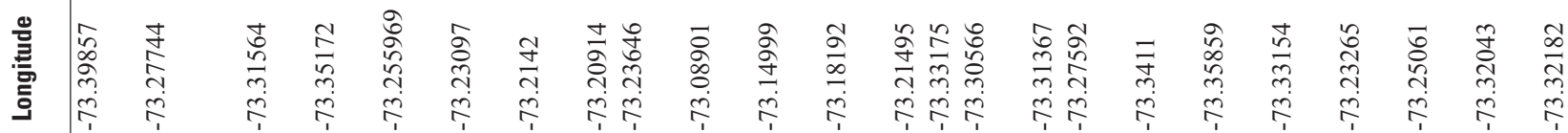

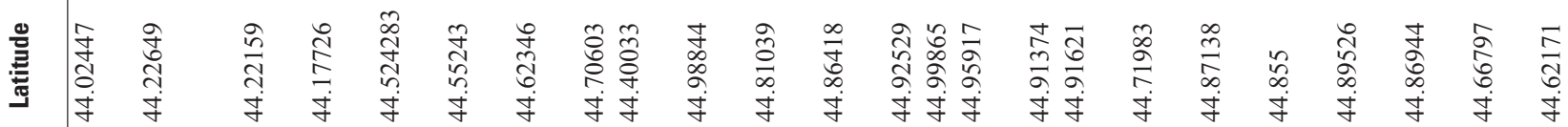

(ด)
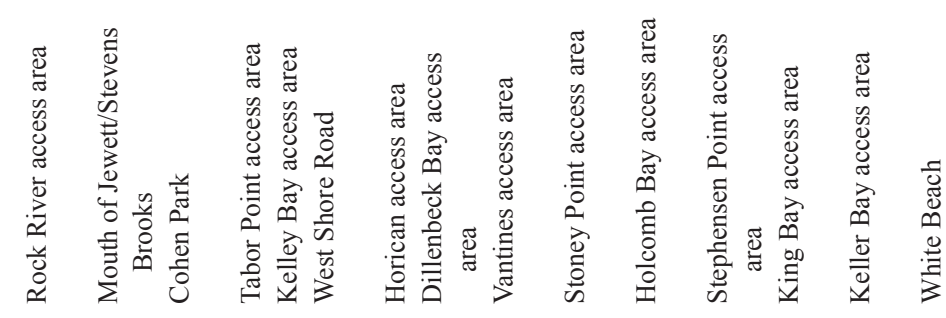


\section{Assessment of Spatial Extent and Height of Flooding in Lake Champlain, May 2011}

Table 3. Flooded area and lake stage from Landsat, moderate resolution imaging spectroradiometer (MODIS), corrected MODIS, and the 10-meter digital elevation model (DEM).

[TERRA is a satellite in descending orbit, crosses the equator at 10:30 a.m., and observes Lake Champlain 10-15 minutes earlier (approximately 10:15 a.m.) daily. AQUA is a satellite in ascending orbit, crosses the equator at 1:30 p.m., and observes Lake Champlain 10 to 15 minutes later (approximately 1:45 p.m.) daily; MODIS, moderate resolution imaging spectroradiometer; DEM, digital elevation model]

\begin{tabular}{|c|c|c|c|c|c|c|}
\hline Image date & Satellite & $\begin{array}{l}\text { Burlington Lake level } \\
\text { (feet) }\end{array}$ & $\begin{array}{l}\text { Richelieu } \\
\text { (feet) }\end{array}$ & $\begin{array}{l}\text { Whitehall } \\
\text { (feet) }\end{array}$ & $\begin{array}{c}\text { Average stage } \\
\text { (feet) }\end{array}$ & $\begin{array}{l}\text { Lake area in mask } \\
\text { (hectares } \times 1,000 \text { ) }\end{array}$ \\
\hline $5 / 24 / 2010$ & Landsat 5 & 96.85 & 96.83 & 96.69 & 96.79 & 114 \\
\hline $7 / 14 / 2011$ & Landsat 5 & 97.05 & 96.96 & 97.02 & 97.01 & 115 \\
\hline $7 / 3 / 2010$ & Landsat 5 & 95.82 & 95.98 & 95.69 & 95.83 & 114 \\
\hline $5 / 11 / 2011$ & Landsat 5 & 102.19 & 102.07 & 102.21 & 102.16 & 137 \\
\hline $9 / 10 / 2009$ & Landsat 5 & 95.64 & 95.62 & 95.44 & 95.57 & 114 \\
\hline $5 / 21 / 2009$ & Landsat 5 & 97.1 & 97.14 & 96.78 & 97.01 & 115 \\
\hline $8 / 28 / 2007$ & TERRA-MODIS & 94.96 & 95.08 & 95.09 & 95.04 & 117 \\
\hline $8 / 28 / 2007$ & AQUA-MODIS & 94.96 & 95.08 & 95.09 & 95.04 & 118 \\
\hline $7 / 3 / 2010$ & TERRA-MODIS & 95.72 & 95.98 & 95.92 & 95.87 & 117 \\
\hline $7 / 3 / 2010$ & AQUA-MODIS & 95.72 & 95.98 & 95.92 & 95.87 & 118 \\
\hline $4 / 30 / 2011$ & TERRA-MODIS & 102.44 & 102.25 & 102.32 & 102.34 & 120 \\
\hline $5 / 1 / 2011$ & TERRA-MODIS & 102.23 & 102.28 & 102.31 & 102.27 & 132 \\
\hline $5 / 10 / 2011$ & TERRA-MODIS & 102.51 & 102.19 & 102.32 & 102.34 & 134 \\
\hline $5 / 10 / 2011$ & AQUA-MODIS & 102.51 & 102.19 & 102.32 & 102.34 & 141 \\
\hline $5 / 11 / 2011$ & AQUA-MODIS & 102.24 & 102.07 & 102.16 & 102.16 & 123 \\
\hline $5 / 11 / 2011$ & TERRA-MODIS & 102.24 & 102.07 & 102.16 & 102.16 & 123 \\
\hline $5 / 12 / 2011$ & AQUA-MODIS & 101.94 & 101.93 & 101.98 & 101.95 & 129 \\
\hline $5 / 12 / 2011$ & TERRA-MODIS & 101.94 & 101.93 & 101.98 & 101.95 & 134 \\
\hline $5 / 25 / 2011$ & AQUA-MODIS & 101.75 & 101.67 & 101.72 & 101.71 & 124 \\
\hline $5 / 30 / 2011$ & TERRA-MODIS & 102.27 & 102.25 & 102.29 & 102.27 & 121 \\
\hline $5 / 30 / 2011$ & AQUA-MODIS & 102.27 & 102.25 & 102.29 & 102.27 & 128 \\
\hline $6 / 3 / 2011$ & AQUA-MODIS & 101.94 & 101.77 & 101.87 & 101.86 & 128 \\
\hline $7 / 14 / 2011$ & TERRA-MODIS & 97.05 & 96.96 & 97.02 & 97.01 & 122 \\
\hline
\end{tabular}

Table 4. Stage/area rating data from imagery and from the digital elevation model (DEM).

[ft, feet; DEM, digital elevation model; LCBP, Lake Champlain Basin Program; na, not available]

\begin{tabular}{cccc}
\hline $\begin{array}{c}\text { Lake stage } \\
(\mathbf{f t})\end{array}$ & $\begin{array}{c}\text { Image lake area } \\
(\text { hectares } \times \mathbf{1 , 0 0 0})\end{array}$ & $\begin{array}{c}\text { DEM lake area } \\
(\text { hectares } \times \mathbf{1 , 0 0 0})\end{array}$ & $\begin{array}{c}\text { Lake area from LCBP } \\
(\text { hectares } \times \mathbf{1 , 0 0 0})\end{array}$ \\
\hline 94.6 & 108.7 & 111.4 & na \\
96.3 & 113.8 & 121.0 & 113.6 \\
98.0 & 118.4 & 127.3 & na \\
99.6 & 123.2 & 131.8 & na \\
101.2 & 128.0 & 134.4 & na \\
102.9 & 132.9 & 136.1 & na \\
104.5 & 138.0 & 138.5 & na \\
\hline
\end{tabular}




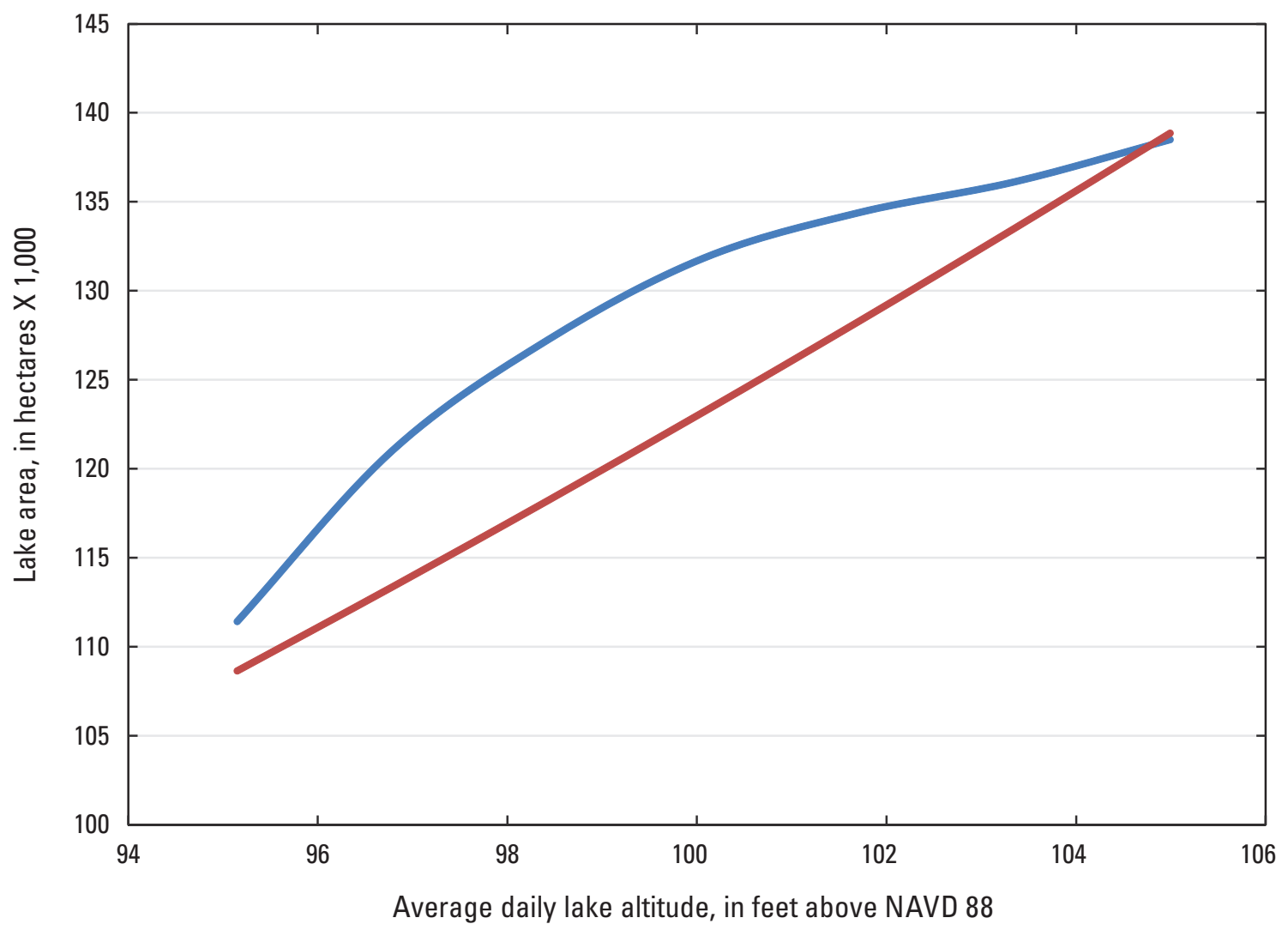

\section{EXPLANATION}

DEM

MODIS image

Figure 7. Relation between lake area, based on the corrected moderate resolution imaging spectroradiometer (MODIS) image and the 10-meter digital elevation model (DEM), and average lake level (stage). 


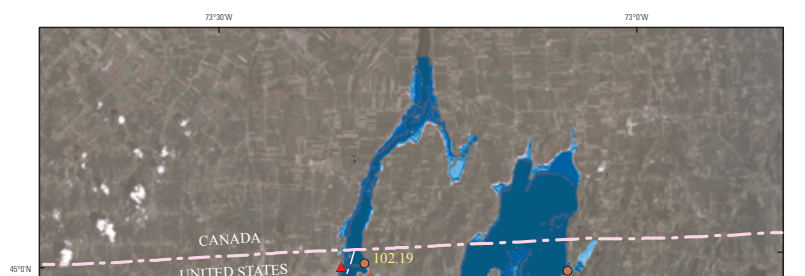

EXPLANATION
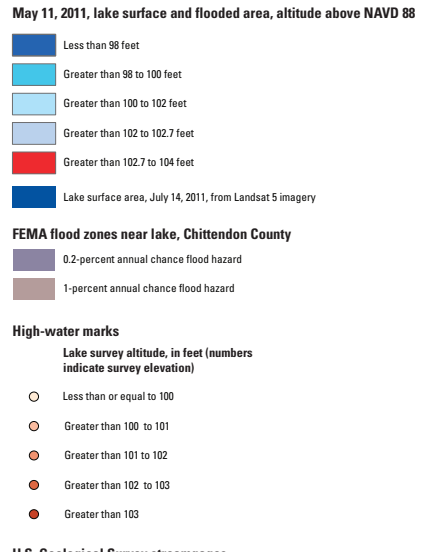

U.S. Geological Survey streamgages

$\Delta$
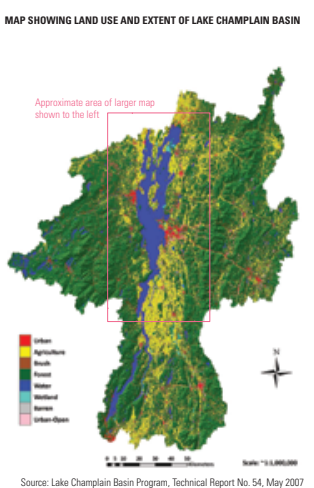

Figure 8. The inundated area of Lake Champlain on May 11, 2011, from Landsat and moderate

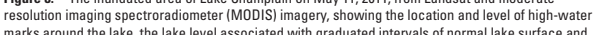
flooded areas, and the digital flood insurance rate map boundaries for Chittenden County obtained from the Federal Emergency Management Agency (FEMA) and the Vermont Department of Environmental Conservation. Red areas indicate flooded areas higher than the average level of the lake laverage of the
three daily mean lake levels for Rouses Point Burlington, and Whitehall gages) for May 11 (11027 feeth: indicating areas where there is the potential for water surface to be higher than expected live f eeet), basis of the gage data. The levels of the lake surface and flooded areas were determined from the 10-meter digital elevation map. The map also shows the lake surface area as observed on July 14, 201 (lake level of 97.5 feet), which approximately corresponds to the graduated lake area below 98 feet.
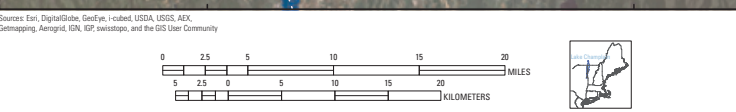

Figure 8. Inundated area of Lake Champlain on May 11, 2011

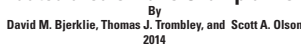

Figure 8. The inundated area of Lake Champlain on May 11, 2011, from Landsat and moderate resolution imaging spectroradiometer (MODIS) imagery, showing the location and level of high-water marks around the lake, the lake level associated with graduated intervals of normal lake surface and flooded areas, and the digital flood insurance rate map boundaries for Chittenden County obtained from the Federal Emergency Management Agency (FEMA) and the Vermont Department of Environmental Conservation. Red areas indicate flooded areas higher than the average level of the lake (average of the three daily mean lake levels for Rouses Point, Burlington, and Whitehall gages) for May 11 (102.7 feet), indicating areas where there is the potential for water surface to be higher than expected level on the basis of the gage data. The levels of the lake surface and flooded areas were determined from the 10-meter digital elevation map. The map also shows the lake surface area as observed on July 14, 2011 (lake level of 97.5 feet), which approximately corresponds to the graduated lake area below 98 feet.

(Click link to view full-size map of figure 8 at http://pubs.usgs.gov/sir/2014/5163/.) 
was about the same at Rouses Point as at Whitehall (mean difference of $0.02 \mathrm{ft}$ ).

The daily maximum lake water-level differences were much greater than daily mean lake water-level differences. The daily maximum water-level difference ranged from +0.6 to $-0.6 \mathrm{ft}$ at Burlington compared to water levels at Whitehall, and +0.4 to $-0.8 \mathrm{ft}$ compared to water levels at Rouses Point. Rouses Point water-level difference ranged from +1.1 to $-0.8 \mathrm{ft}$ compared to water levels at Whitehall. These differences indicate that mean water levels were fairly similar but varied as much as $1 \mathrm{ft}$ up and down (throughout the reach of) the lake, with a slightly higher level near the middle of the lake at Burlington.

Daily water-level differences between the Rouses Point and Whitehall gages through the flooded period are shown in figure 9. (A hydrograph showing the actual lake water levelsnot just the differences - for the Rouses Point, Burlington, and Whitehall gages is shown on fig. 3). These data (water-level differences) show no apparent correlation with lake level and illustrate the variable dynamics that occur up and down the lake. Similar variation in the differences occurs between all of the stations, suggesting that common mechanisms cause the differences but that the differences are independent of the static water level in the lake. This condition likely reflects the local effects of wind and river influx.

The HWMs similarly show significant variation around the lake, with differences as much as $2 \mathrm{ft}$ between the highest and lowest lake levels. These data show greater variation in levels than is evidenced by the three lake level gages at Whitehall, Rouses Point, and Burlington (which indicated variation of up to $1 \mathrm{ft}$ ). As previously discussed, the distribution of HWM levels show a general pattern, with the highest levels along the eastern shoreline and in the northern part of the lake and the lowest levels occurring in protected areas on the western shorelines.

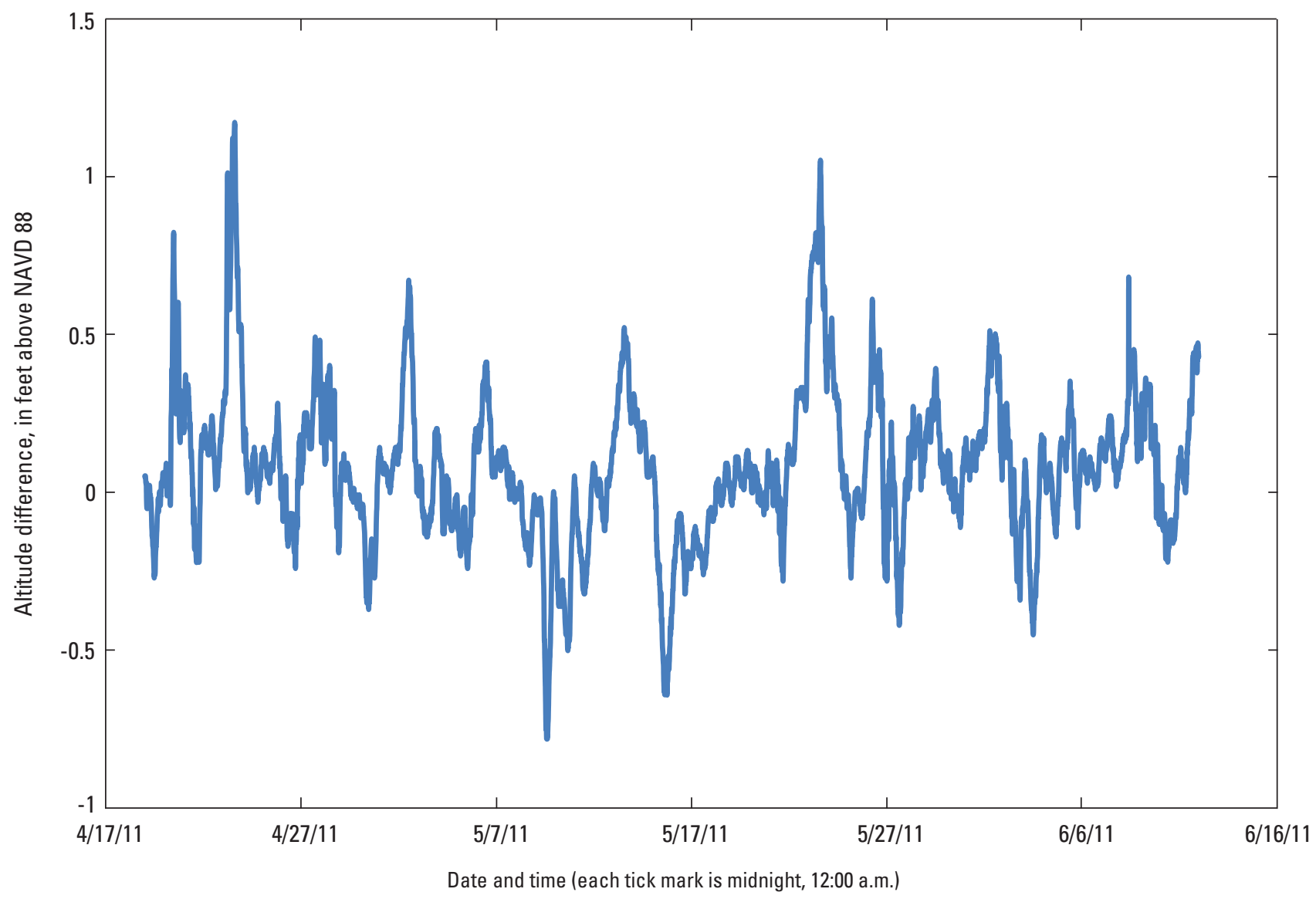

EXPLANATION

Rouses Point altitude minus Whitehall altitude

Figure 9. Differences in daily mean water levels, plotted against day from April to June 2011, between the Rouses Point and Whitehall gages. 


\section{Summary}

The flooding in Lake Champlain during May 2011 resulted in the highest water levels known (since 1827). The high water levels were sustained above flood stage for over a month, resulting in unprecedented flood damages along lake shorelines and downstream in communities along the Richelieu River. Satellite imagery, used in combination with ground-based information, provided an efficient and effective regional lake-wide observation platform. Differences in water levels around the lake were evident from the intersection of the observed inundation area (based on imagery) and the digital elevation model (DEM), from the lake level gage data, and from the high-water marks (HWMs). Mean daily lake level varied along the shoreline by as much $1 \mathrm{ft}$. Water-level variation along the shoreline indicates the effect of wind and other dynamics as well as locally higher water at the mouth of rivers. There are several locations where differences between flooded areas observed from satellite imagery and flood zone boundaries were identified, indicating the need for updated flood mapping that accounts for the wind and river inflow effects on lake level. Future modeling of lake flooding should also consider these effects. To address variation in water level due to wind effects and other dynamics including river inflows, 2-dimensional models or 3-dimensional lake models with bathymetry may be required. The lake inundation area versus stage ratings developed from the imagery in this study, along with the general description of the lake level variations, can be used to help calibrate future modeling.

\section{References Cited}

Kiah, R.G., Jarvis, J.D., Hegemann, R.F., Hilgendorf, G.S., and Ward, S.L., 2013, Hydrologic conditions in New Hampshire and Vermont, water year 2011: U.S. Geological Survey Open-File Report 2013-1135, 36 p., http://pubs. usgs.gov/of/2013/1135/.

Lake Champlain Basin Program, 2013, Flood resilience in the Lake Champlain Basin and Upper Richelieu River, April 11: Lake Champlain Basin Program report, 93 p.

Lake Champlain Basin Program, 2002, The Lake Champlain Basin Atlas: Grand Isle, Vt., Lake Champlain Basin Program, http://atlas.lcbp.org/HTML/intro.htm.

Lake Champlain Research Consortium, 2004, About Lake Champlain: Lake Champlain Research Consortium, at http://academics.smcvt.edu/lcrclaboutlake.html.

Medalie, Laura, and Olson, S.A., 2013, High-water marks from flooding in Lake Champlain from April through June 2011 and tropical storm Irene in August 2011 in Vermont: U.S. Geological Survey Data Series 763, 15 p., http://pubs.usgs.gov/ds/763/.
National Oceanic and Atmospheric Administration, 2012, \#2 weather event-Lake Champlain record flooding: National Oceanic and Atmospheric Administration Top 5 Weather Events of 2011 Across the North Country Web page, accessed February 2013, at http://www.erh.noaa.gov/ btv/events/Top5_2011/2.php.

National Oceanic and Atmospheric Administration, [n.d.], National Weather Service Burlington, Vt., Office-Inundation: National Oceanic and Atmospheric Administration Web page, accessed February 2013, at http://www.erh.noaa. gov/btv//html/hydro/inundation/inundation.html.

Olson, S.A., and Bent, G.C., 2013, Annual exceedance probabilities of the peak discharges of 2011 at streamgages in Vermont and selected streamgages in New Hampshire, western Massachusetts, and northeastern New York: U.S. Geological Survey Scientific Investigations Report 2013-5187, 17 p., http://dx.doi.org/10.3133/sir20135187.

Pan, Feifei, Liao, Jinjuan, Li, Xinwu, and Guo, Huadong, 2012, Application of the inundation-area lake level rating curves constructed from the SRTM DEM to retrieving lake levels from satellite measured inundation areas: Computers and Geosciences, v. 52, p. 168-176.

Shanley, J.B., and Denner, J.C., 1999, The hydrology of the Lake Champlain Basin, in Manley, T.O., and Manley, P.L., eds., Lake Champlain in transition-From research toward restoration: Washington, D.C., American Geophysical Union, Water Science Applications, v. 1, p. 41-66, http://www.agu.org/books/ws/v001/WS001p0041/ WS001p0041.pdf.

U.S. Geological Survey, 2013a, Explore map of USGS gages in the Lake Champlain watershed: U.S. Geological Survey Web page, accessed February 2013, at http://vt.water.usgs. gov/echo_gage/basin_map.htm.

U.S. Geological Survey, 2013b, Frequently asked questions about the Landsat missions: U.S. Geological Survey Landsat Missions Web page, accessed February 2013, at http://landsat.usgs.gov/Landsat_7_ETM_SLC_off_data.php.

U.S. Geological Survey, [n.d.], Elevation: U.S. Geological Survey National Elevation Dataset, accessed February 2013, at $h t t p: / / n a t i o n a l m a p . g o v / e l e v a t i o n . h t m l$.

Vermont Department of Environmental Conservation, [n.d.], Digital flood insurance rate maps: Vermont Department of Environmental Conservation Web page, accessed February 2013, at http://www.vtwaterquality.org/rivers/htm/ rv_DFIRMs.htm. 
Prepared by the Pembroke Publishing Service Center.

For more information concerning this report, contact:

Office Chief

Connecticut Office

New England Water Science Center

U.S. Geological Survey

101 Pitkin Street

East Hartford, CT 06108

dc_ct@usgs.gov

or visit our Web site at:

http://ct.water.usgs.gov 


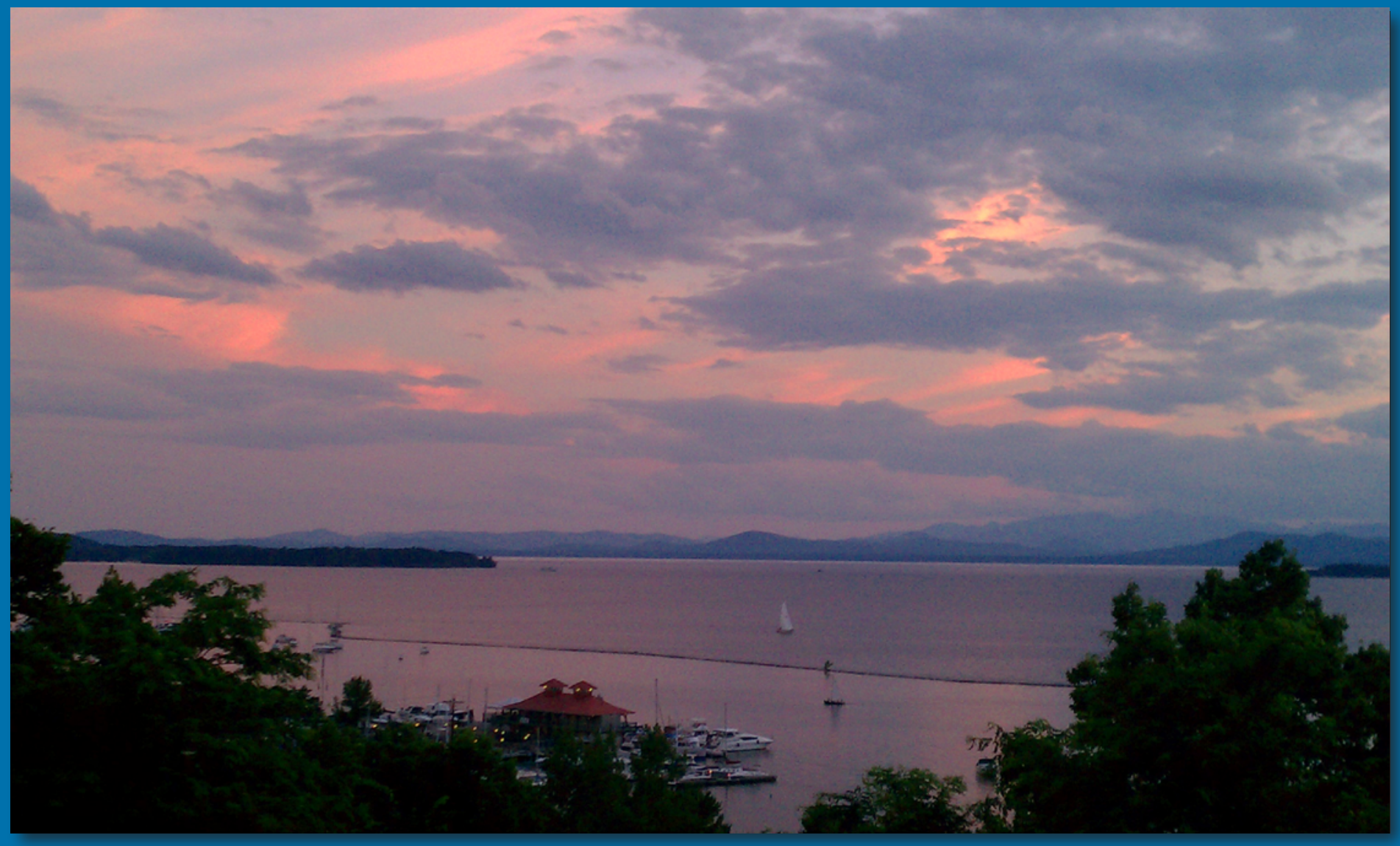

